\title{
Economic impact of local vaccine manufacturing
}

\author{
Kerina Tull \\ University of Leeds Nuffield Centre for International Health and Development \\ 23 February 2021
}

\section{Question}

What are the lessons learned from vaccine manufacturing in developing countries such as India, Indonesia, Thailand, Vietnam, Brazil, Cuba, Mexico? Consider challenges and positive spillover effects.

\section{Contents}

1. Summary

2. Introduction

3. India

4. Indonesia

5. Thailand

6. Vietnam

7. Brazil

8. Cuba

9. Mexico

10. References

The K4D helpdesk service provides brief summaries of current research, evidence, and lessons learned. Helpdesk reports are not rigorous or systematic reviews; they are intended to provide an introduction to the most important evidence related to a research question. They draw on a rapid deskbased review of published literature and consultation with subject specialists.

Helpdesk reports are commissioned by the UK Foreign, Commonwealth, and Development Office and other Government departments, but the views and opinions expressed do not necessarily reflect those of FCDO, the UK Government, K4D or any other contributing organisation. For further information, please contact helpdesk@k4d.info. 


\section{Summary}

Over a period of time, a tier of mostly middle-income developing countries has developed a considerable pharmaceutical and vaccine production capacity (WHO, 2011). However, outcomes have not always been positive for domestic manufacturers in developing countries. Economic and health lessons learned from vaccine manufacturing in developing countries include challenges and positive spillover effects. Evidence for this rapid review is taken from south and southeast Asia (India, Indonesia, Thailand, Vietnam), and Latin America (Brazil, Cuba, Mexico). Lessons learned to highlight include:

- All seven of these countries are part of the Developing Countries Vaccine Manufacturers Network (DCVMN). India, Indonesia, Thailand, and Vietnam are known to have sizeable pharmaceutical industries (WHO, 2011). In Brazil, local vaccine companies have been successful, although it is not a very easy market (Parrish, 2020). Government support was found to be important (Brazil, Cuba).

- Brazil and Cuba are good learning examples for vaccine production set-up by public institutions (Milstien et al., 2007; Milstien \& Kaddar, 2010; WHO, 2015a), while India is an example for private manufacturers (Milstien et al., 2007; Kaddar et al., 2014). Manufacture in Thailand and Vietnam has not developed to the same level as the more successful public sector manufacturers, despite concerted effort.

- Regulation: As with other technology-driven industries, vaccine manufacturing is also highly-regulated by national policy and dominated by the private sector (WHO, 2015; Plotkin et al. (2017). Support from WHO is mostly technical; they have heavily supported regulatory system development in developing countries with vaccine manufacturing capacities, and they did this through creating institutional development plans based on National Regulatory Authority (NRA) assessment (Makenga et al., 2019). In Cuba, Brazil and India it was the development of vaccine production that pushed Governments to improve their NRAs.

- Vaccine manufacturing remains a challenging and costly endeavour (Plotkin et al., 2017). The developing country vaccine market has historically been high volume, low profit traditional vaccines. This was not especially attractive to most vaccine-producing multinational companies (MNCs) (Milstien \& Kaddar, 2010). Vietnam shows that emerging nations no longer limit their ambitions to attracting foreign direct investment (FDI) from European or North American companies, but seek to become innovative.

- Public-private partnerships (PPPs) are vital for Thailand to accelerate vaccine development and production. However, this did not work for Mexico due to a history of political instability (Carrillo, 2017) - from the standpoint of self-sufficiency, not enough vaccines have been produced since 1998 (Tamez et al., 2016).

- Pharma growth: India leads in terms of cheaper vaccines available for the country and internationally. A higher compound annual growth rate (CAGR) of the vaccine business than the pharma business may explain this. The pharma sector in Brazil has been a major contributor to the world's vaccine advancements in R\&D (Parrish, 2020).

- Unlike the other countries in the Association of Southeast Asian Nations (ASEAN) region, Indonesia, Thailand and Vietnam are producing traditional vaccines domestically, with each pursuing its own priorities (Brückler, 2013). Vietnam will continue to have a negative vaccine trade balance due to its focus on catering to the domestic market (EVBN, 2014: 
32). In Latin America, Mexico has not been so successful in local vaccine manufacture. The Cuban biotechnology sector is distinctive because it is owned by the state and not supported by speculative financing.

- Data on positive spillovers effects focus on skills development. Technology transfer can also create positive spillover effects into associated industries and into the supporting public sector research infrastructure (IFPMA, 2015: 6). Estimated data for positive spillovers has been found (India, Brazil). However, studies that only estimate treatment effects without measuring spillover effects will underestimate the effectiveness of the intervention if positive spillovers are present (Benjamin-Chung et al., 2017). Although vaccines may cost more to develop than therapeutics, they also have the potential to provide far greater benefits to society (Xue \& Ouellette, 2020). A systematic review on spillover effects on health outcomes in low- and middle-income countries (LMICs) found the strongest evidence for spillovers through reduced disease transmission, particularly vaccines and mass drug administration, e.g. in their National Immunisation Programmes (Indonesia, Brazil, Cuba).

- There have been numerous successes in transferring new technology to existing vaccine manufacturers using public-private partnerships (e.g. India, Brazil, Indonesia). Manufacturers, notably those in Mexico and Brazil, as well as in other countries not traditionally associated with vaccine production, will opt for partnerships with multinational companies (MNCs) to access newer technologies. This route will normally not result in their development as innovative producers of vaccines; however, it can be seen as the best route to assure newer vaccines to their countries.

- Technology transfer is an effective and efficient tool to reduce product development cost, and shorten the time-to-market. It has been used in India, Indonesia, Thailand, Brazil, and Mexico. Development of the Health Economic Industrial Complex in Brazil has helped to create jobs and national economic growth (WHO, 2011: 39). Vietnam has a good education system considering its level of development capable of producing an ample quantity of skilled labour that can participate in a wide range of manufacturing (Gintin, 2019). Indonesia has a lack of health-care workers (Milken Institute, 2016: 17).

Scientists are hailed as heroes in Cuba, a prestige that helps limit brain drain despite low salaries and difficult conditions (Marsh, 2020). However, wage increases do not appear to be retaining a motivated workforce and boosting productivity in Cuba (O'Farrill, 2018).

- Foreign direct investment (FDI) and trade: Vietnam manufacture has benefited from a progressive FDI policy; Indonesia, however, has not (Ginting, 2019). Special economic zones (SEZs) have been used in Thailand and Cuba to promote FDI in health-related activities.

- Vaccine exports and imports: Some companies have formed partnerships with international players for the development of more niche vaccines to supply the global market (e.g. Cuba). India is the only one of the selected countries that has become vaccine self-sufficient (Lahariya, 2014). Therefore, export earnings for a number of vaccine manufactures in India are available (Saha, 2021). Indonesia currently buys and distributes vaccines for free at an estimated cost of about USD5.3 billion. India's reliance on pharma ingredient imports has risen over the past few decades due to the higher cost of domestic production (Nair, 2020). Research shows that exporting plasma results 
in alternative processing using nucleic acid-based technologies support fast and flexible vaccine development and production (Rauch et al., 2018; Raw \& Higashi, 2008).

- Vaccine pricing: In Brazil, the Institute of Drug Technology (Farmanguinhos) plays a strategic role by acting as a regulator of market prices of antiretroviral drugs. However, market forces and parameters for vaccines are different from those for drugs (WHO, 2011: 5). Multinational companies (MNCs) can control pricing. The Serum Institute of India tends not to enter agreements with MNCs, as it wants to control the process and the market (Milstien et al., 2007).

- Challenges: a lack of awareness and understanding of vaccines among the health community; limitations in affordability/ access, and constraints to manufacturing and supply have been found in India (Bhadoria et al., 2012). Lack of know-how is a possible main barrier to local vaccine production (e.g. Vietnam, Cuba). Lack of patents for novel vaccine concepts from several developing countries can be one of the obstructions to local production (e.g. Brazil). For more recently produced vaccines, and possibly for future vaccines, intellectual property may be an additional barrier to access (WHO, 2011).

Although data on locally manufactured drugs on the balance of trade was available, this was not readily available for vaccine manufacturing. The evidence used in this review was taken from grey and academic literature, as well as interview with economic specialists. Although market reports on vaccine production are available for most of these countries, their data is not in the public domain.

\section{Introduction}

\section{Economic impacts of local manufacture}

Pharmaceutical and vaccine production capacity has been developed over a period of time in some (mostly middle-income) developing countries (WHO, 2011: 6). Certain countries have achieved vaccine self-sufficiency. All seven of the countries included in this review are part of the Developing Countries Vaccine Manufacturers Network (DCVMN). ${ }^{1}$ Two of every three children born in the world are immunised with at least one vaccine from a DCVMN manufacturer (WHO, 2011: 12-13). When more vaccine manufacturers are able to enter the market, supply for countries increases while cost decreases. Increased DCVM competition has been shown to lower prices of vaccines (Padmanabhan et al., 2010).

\section{Positive spillover effects ${ }^{2}$}

Vaccines are almost always cost-effective in terms of public health outcomes (WHO, 2011: 5). There is well-documented evidence of spillovers of many vaccines in developing countries (i.e. 'herd effects' - Edejer et al., 2005; Ozawa et al., 2012). This can justify the cost-effective

\footnotetext{
${ }^{1}$ This is a voluntary public health-driven alliance of vaccine manufacturers that aims to make a consistent supply of good-quality vaccines accessible to developing countries, especially the vaccines used in the World Health Organization (WHO) Expanded Program on Immunization (EPI).

2 Spillovers are described using many different names in different subfields and disciplines - including treatment externalities, contamination, herd immunity, and indirect effects, among others.
} 
scale-up of immunisation efforts to a global level via programmes, such as those with the Global Alliance for Vaccines and Immunization (Gavi, the Vaccine Alliance) (Benjamin-Chung et al., 2017). Benefits for individuals other than the vaccinated patient could defend the extra costs of vaccine development from a social welfare point of view (Xue \& Ouellette, 2020). International spillovers are essential for developing countries to catch up with advanced economies, and this matter ranks high in the development policy agenda. ${ }^{3}$ However, studies that only estimate treatment effects without measuring spillover effects will underestimate the effectiveness of the intervention if positive spillovers are present (Benjamin-Chung et al., 2017).

\section{Challenges}

Emerging economies that have been making increasingly sophisticated vaccines now have experienced workforces, so know-how is less of a challenge (WHO, 2011: 30). However, maintaining that know-how may be an issue for some countries. Other details to consider include sustainable funding in a variety of areas along the value chain, or sustaining viability when exporting vaccines or producing new technology vaccines (Milken Institute, 2016: 17). A fundamental relationship that has been the focus of many studies is the causal link between improved health and economic productivity. However, this is actually a challenging relationship to estimate rigorously (Dupas \& Miguel, 2016: 4).

\section{India}

India currently is one of the leading manufacturers and suppliers of vaccines in the world. It accounts for approximately $60 \%$ of the total vaccines supplied to UNICEF, since the cost of manufacturing and clinical trials in India is relatively lower than in developed countries ${ }^{4}$ Several vaccine institutes have been set up throughout the whole of the $20^{\text {th }}$ and $21^{\text {st }}$ centuries (Lahariya, 2014).

\section{Capital support and framework}

A review of the history of vaccination in India by Lahariya (2014) shows vaccine manufacturing has moved from public to private units. Foreign direct investment (FDI) inflow to India has been on a long-term growth trend (UNCTAD, 2020: 41). Although analysis of data (for years 2000 to 2019) shows that a larger share of the FDI equity (gross FDI includes equity, re-invested earnings, and other capital) has gone into services, these are mainly financial services, software, telecommunication, construction and trading than manufacturing (although drugs and pharmaceuticals manufacture are included).

One example of a successful quasi-private sector manufacturer Shantha Biotechnics Ltd ${ }^{5}$, acquired by multinational company (MNC) Sanofi-Aventis, as well as partnering with an international public health group (International Vaccine Institute). Because of the competition, it

\footnotetext{
${ }^{3}$ World Bank (2010). Innovation Policy: A Guide for Developing Countries. World Bank Publications. The World Bank.

${ }^{4}$ Dr Anand Kumar, Managing Director Indian Immunologicals Ltd \& Director Pristine Biologicals (NZ) Ltd.

${ }^{5}$ It was the first Indian company to develop, manufacture and market recombinant vaccine human healthcare products in India. It caters to major international markets including Asia-Pacific, Africa, Commonwealth of Independent States, and Latin American countries in addition to international organisations UNICEF and the Pan American Health Organization (PAHO).
} 
has been able to reduce costs of quality vaccines. Since 2013, Shantha Biotechnics's impact on public health through the supply of oral cholera vaccine to WHO has contributed significantly to global cholera control. ${ }^{6}$ Strong regulation, as well as significant infusion of, improvement and standardisation of technology through collaboration with the non-profit aided in its success. US National Institutes of Health's (NIH) National Cancer Institute (NCl) and Johns Hopkins also partnered with Shantha Biotechnics to commercialise L2-based HPV vaccine technology and improve access in resource-poor settings (Padmanabhan et al., 2010).

However, a number of factors have been found to subdue the growth and penetration of vaccines in India, both in the public and private markets:

- vaccine manufacturing entails high fixed costs, amounting to $60 \%$ of total cost; the need for scale trumps any labour cost advantages in emerging markets (Bhadoria et al., 2012: 18);

- while Indian vaccine manufacturers are increasingly sophisticated about managing innovation, they feel challenged in their ability to interpret patent claims or to challenge dubious ones (Milstein et al., 2007; Padmanabhan et al., 2010). Thus, they dedicate more time and resources to "invent around" the patent rather than risking infringement, that is, to avoid the use of the specific technology or avoid production of the product altogether;

- there are difficulties in introducing new vaccines into the country's massive universal immunisation programme (UIP). Vaccines are provided free under the UIP, but only for a few highly communicable and life-threatening diseases. The Indian Government usually includes a vaccine in the UIP only when it is priced at less than a few US dollars per dose (Bhadoria et al., 2012: 20), and

- obtaining vaccines through the private system can be expensive. Hence some newer vaccines, for e.g. pneumococcal vaccine, can be afforded only by $\mathrm{GSS}^{7}$, when the cost is lowered by local manufacturing. A compounding factor is that in India, most medical insurance policies (including corporate insurance) do not cover vaccination, unlike in China and developed countries.

\section{Pharma growth and vaccine access}

The Indian vaccine market has exhibited strong recent growth. It reached a value of INR59 billion in 2016, growing at a compound annual growth rate (CAGR) of nearly $18 \%$ during 2009 2016. As noted by the latest market report by IMARC Group, ${ }^{8}$ the Indian vaccine market size reached INR94 billion (USD1.3 billion) in 2019. It is predicted to reach INR252 billion (USD3.5 billion) by 2025 , encouraged by significant assistance from the Government.

\footnotetext{
6 Shailesh Ayyangar, Managing Director - India and VP - South Asia, Sanofi.

${ }^{7}$ Globals, Strivers and Seekers defined as those with an annual household income of greater than INR2 lakh (USD 2,746) based on 2000 prices. The Globals are the super-rich elite; the Strivers and Seekers constitute the middle class.

8 IMARC (2019). Indian Vaccine Market Report and Forecast 2020-2025: https://www.imarcgroup.com/vaccinemarket-india-catalysed-by-government\#: :text=Billion\%20by\%202025-

,Indian\%20Vaccine\%20Market\%20to\%20Reach\%20INR\%20252\%20Billion\%20by\%202025,by\%20Significant\%2 0Assistance\%20from\%20Government\&text=As\%20per\%20the\%20latest\%20report,INR\%2094\%20Billion\%20in $\% 202019$
} 
The Indian pharmaceutical industry is reported to be the third largest in the world in terms of volume, and 14th largest in terms of value. ${ }^{9}$ Indian production also dominates its domestic pharmaceutical market, with several biologicals manufactured in abundance, and at affordable prices. The country has retained self-sufficiency through indigenous production of formulations (Lahariya, 2014). ${ }^{10}$ Serum Institute of India's newly licenced pneumococcal vaccine PNEUMOSIL is an important addition to their arsenal because it's designed to provide the same level of protection as the other WHO-prequalified (PQ) ${ }^{11}$ pneumococcal conjugate vaccine (PCVs), but at the unprecedentedly low Gavi price of USD2 per dose (or USD6 per child). ${ }^{12}$ Currently, the pharmaceutical industry has been freeing up capacity, and pushing ahead with investments to help support a global vaccination campaign for COVID-19. ${ }^{13}$

\section{Vaccine export and imports}

India continues to be one of the leading exporters of formulations or generic medicines to the global market. ${ }^{14}$ Official data shows India's pharmaceutical exports of USD19.27 billion and imports in 2018-19 was USD10.43 billion with exports of USD19.27 billion (Nair, 2020). Research shows that India is eager to emerge as a reliable alternative China, to bail out countries that have caught up in China's new export rules for active pharmaceutical ingredients (APIs) (Nair, 2020). Some Indian companies now produce for export with large MNCs:

Case studies:

- Bharat Biotech International Ltd started operation in 1996. In a short span, it has become a leading biotechnology company, with over 160 patents. It became the largest rabies vaccine producer after the acquisition of Chiron Behring from the MNC GlaxoSmithKline (GSK) in March 2019. Net sales for FY19 were INR 763.3 crore (USD105 million), while net profit was INR 111.6 crore (USD 15.4 million). Due to its low base, the growth figures are impressive: the five-year net sales CAGR was $23.6 \%$ while the same for net profit was $43.3 \%$. Its export earnings were $37 \%$ of its net sales in 2019 (Saha, 2021).

- Cadila Healthcare, the fifth largest pharmaceutical company in India, produces COVID19 treatment drugs like Remdesivir. It is also developing an indigenous vaccine for the novel coronavirus. It has received Government approval for phase-III trials on 26,000 Indian patients. Its consolidated net sales for FY19 were INR 14,253.1 crore (USD 1.9 million), while net profit for the financial year was INR 1,176.1 crore (USD 162,003). More

\footnotetext{
${ }_{9}^{9}$ Special Report: India's Pharmaceutical Industry: https://glintpay.com/special-reports-en_us/special-reportindias-pharmaceutical-industry/

10 The country was made self-sufficient for tetanus anti-toxin and anti-snake venom serum, followed by DTP (Diphtheria, Tetanus and Pertussis) group of vaccines, and then later on MMR (measles, mumps and rubella) group of vaccines.

${ }_{11}$ WHO prequalification (PQ) ensures vaccines used in immunisation programmes are safe and effective. It provides Member States and procurement agencies, such as Gavi, the Global Fund and UN organisations like UNICEF, with the information required to purchase vaccines matching the specific needs of the programme: https://www.who.int/medicines/regulation/prequalification/prequal-vaccines/about/en/

12 PATH (2020). Vaccine options for preventing pneumonia just got better in India. 18 August 2020:

https://www.path.org/articles/vaccine-options-preventing-pneumonia-just-got-better-india/

13 India to continue export of medicines, including vaccines: PM Modi. 9 January 2021:

https://www.reuters.com/article/india-modi-idUSKBN29E084

14 In the case of raw materials - intermediaries and APIs - China enjoys the number one position on the global stage.
} 
than one-third of its revenue earnings are from exports (Saha, 2021). However, Cadila's pricing details for the vaccine are unavailable.

- Pune-based Serum Institute of India: established in 1966, is ranked as India's leading biotechnology company, with over 1.5 billion doses produced in several available facilities and sold. Vaccines are also accredited by the World Health Organization (WHO) Geneva, and are being used in approximately 170 countries across the globe in their National Immunisation Programmes. ${ }^{15}$ In 2018-19, its net sales were at INR 5,238 crore (USD 721,576), while profit after tax was INR 2,252 crore (USD 310,231). The fiveyear (2014-2019) CAGR for sales was 8.1\%, while the five-year CAGR for profit after tax was $5.3 \%$. Its export earnings were over two-third of its net sales in 2019. Total assets were INR 16,703 crore (USD 2.3 million) at the end of 2019 (Saha, 2021). Serum Institute of India tends not to enter agreements with MNCs, as it wants to control the process and the market (Milstien et al., 2007) ${ }^{16}$ Currently, the Indian Government has been negotiating with the Serum Institute of India to bring down the price of AstraZeneca's COVID-19 vaccine, before clearing any shipments for exports or private sales. ${ }^{17}$

However, India's reliance on pharma ingredient imports has risen over the past few decades due to the higher cost of domestic production. The price gap with China has reached as much as 20-30\%, particularly for energy-intensive fermentation-based ingredients used in anti-infective vaccines (Nair, 2020).

\section{Positive spillover effects}

There are limited positive spillover effects noted in the literature: only one trial intervention by Sur et al., (2009) reported positive spillover estimates for typhoid vaccine (44\% decrease in typhoid, no deaths or health events related to typhoid) (Benjamin-Chung et al., 2017).

\section{Skills development}

Technological advancements and improved cold chain storage facilities have led to increased vaccine production capacity in the country. However, in terms of skills, research shows that there has been a limited focus on training in vaccinology and immunology in India (Lahariya, 2014). In 2010, the India Vaccinology Course (INDVAC) ${ }^{18}$, was implemented as an educational method to address the need for knowledge and research. However, the course is aimed at specialists already working in vaccinology.

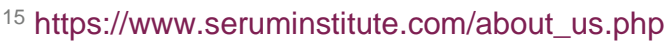

16 The dominance of the multinational companies in the vaccine trade market (e.g. GSK, Pfizer, Merck Sharp \& Dohme [MSD]) was predicted to subside in the coming years; however, this was before the COVID-19 epidemic. 17 The vaccine would be priced at about INR1,000 (USD13.55) per dose for the private market in India and would cost the Government approximately INR250 (USD3.40) per dose:

https://economictimes.indiatimes.com/industry/healthcare/biotech/pharmaceuticals/bharat-biotech-pursues-covid19-vaccine-approval-in-over-40-countries/articleshow/81085493.cms

$18 \mathrm{http}: / /$ www.indvac.org/
} 


\section{Indonesia}

The state-owned company Bio Farma is the only vaccine and serum manufacturer in Indonesia. Its traditional focus has been on commodity type paediatric vaccines. ${ }^{19}$ Vaccination through the National Immunization Program (NIP) is compulsory in Indonesia (Milken Institute, 2016: 7). Founded to serve the local market, it was the first ASEAN-based vaccines manufacturer to achieve WHO PQ status, enabling participation in UNICEF tenders for DTP, DTP-HepB, HepB, measles, and oral polio vaccines (Brückler, 2013). Although NIP costs are covered by its universal health-care system (or JKN, Jaminan Kesehatan Nasional); any vaccines not included in the government programme must be paid for out of pocket. Private health insurance may not cover them either (Milken Institute, 2016: 7).

\section{Capital support and framework}

Indonesia is new to self-financing its vaccine manufacturing sector. Indonesia is transitioning from donor-based funding because it has become more affluent, and is now a middle-income country according to the 2020 World Bank classifications. Therefore, it is no longer considered a priority country for global donors. Extensive support from Gavi ended in 2018 (Fonjungo et al., 2020: 2; Milken Institute, 2016: 7). In the past, as much as 98\% of Bio Farma's research funds came from abroad, with the Netherlands, Germany, Australia and South Africa being the biggest sources. ${ }^{20}$ The European Union poured aid into the Indonesian health sector from the 1980s, but stopped in early 2014 due to this new affluence..$^{21}$ This has resulted in an increase in the role of Government in the Indonesian healthcare industry. The Government has been able to provide more money to develop the country's universal healthcare system: IDR100 billion (USD 7.7 million) through the country's Ministry of State-owned enterprises was allocated in 2010 , however, this was only able to support five years of basic vaccine research.

\section{Pharma growth and vaccine access}

Indonesia is one of the fastest growing pharmaceutical markets in Asia, but the biopharmaceutical industry is in the nascent stage. ${ }^{22}$ The pharmaceutical market is worth USD6 billion. According to Global Data, it is ranked the largest market in the ASEAN regions, with the market value expected to reach IDR141.6 billion (USD10.11 billion) by 2021. Beyond traditional vaccines, Indonesia's exposure to H5N1 influenza and its resulting contributions to global influenza outbreak monitoring have driven further vaccine developments (Brückler, 2013).

There are several major players in the Indonesia pharmaceutical market. ${ }^{23}$ The majority of pharmaceutical companies are located in West Java and Jakarta due to favourable tax

\footnotetext{
${ }^{19}$ It developed the 5-in-1 shot pentavalent vaccine which protects against DTP, hepatitis B, and Hib.

20 Indonesia is becoming a global vaccine player, but so is China. 8 April 2015:

https://www.manufacturingchemist.com/news/article_page/Indonesia_is_becoming_a_global_vaccine_player_but so_is_China/107395

${ }^{21} \mathrm{Dr}$ Carole Brückler, Head of Asia-Pacific operations for Deallus Consulting in Singapore.

22 Ken Research (2018). Indonesia Pharmaceutical Market Outlook to 2022:

https://www.kenresearch.com/healthcare/pharmaceuticals/indonesia-pharmaceutical-market/143542-91.html

23 These include: PT Kalbe Farma; PT Sanbe Farma; PT SOHO Global Health; PT Dexa Medica; PT Pharos; PT Kimia Farma; PT Tempo Scan Pacific Tbk; PT Merck Tbk; Fahrenheit; Sanofi Aventis, PT Novell Pharmaceutical Laboratories; Biofarma; Darya Varia, and Konimex.
} 
incentives, ${ }^{24}$ well-developed infrastructure, and greater access to medicinal herbs. Broadly speaking, FDI to manufacturing in Indonesia had been decreasing in the last few years (Ginting, 2019). ${ }^{25}$ However, latest records show that total FDI in Indonesia is rising: FDI inflows to Indonesia grew by $14 \%$ to a record level of USD23 billion, with strong investments in manufacturing (UNCTAD, 2020: 43).

\section{Vaccine exports and imports}

World Bank trade statistics ${ }^{26}$ show that Indonesia is the biggest vaccine exporter in

Southeast Asia. The country earned USD76.3 million from vaccine exports in 2010, which grew by $25.2 \%$ to USD95.5 million in 2019. Indonesia currently buys and distributes vaccines for free at an estimated cost of about USD5.3 billion. ${ }^{27}$ To date, every vaccine used in Indonesia's NIP is manufactured by Bio Farma, whose "commitment was to develop national vaccine industry's independence, such that the Government is not required to import vaccines to fulfil national needs" ${ }^{28}$ However, this has now changed due to COVID-19. ${ }^{29}$

\section{Positive spillover effects}

There is limited evidence on positive spillover effects of vaccine manufacture. A family may not be able to afford a vaccine, but the Conditional Cash Transfer (CCT) programme could make this possible (Milken Institute, 2016: 14). Research by Kusuma et al. (2017) shows that Indonesia's large-scale household CCTs scheme known as Program Keluarga Harapan (PKH) significantly contributed to an increase in child vaccination rates for most vaccines, particularly in the treatment group (up to $30 \%$ ). However, data on potential spillovers of this programme is unavailable.

\section{Skills development}

Bio Farma's credits its success to committed project management, and availability of competent staff. As Bio Farma vaccines are WHO pre-qualified, they also have access to the global skills market through international partnerships. ${ }^{30}$ For example, through a technology transfer from the Biken Institute of Japan, together with WHO and BioFarma all worked towards developing influenza vaccines during the 2009 pandemic (Brückler, 2013). Bio Farma has also

\footnotetext{
24 Indonesia passed the so-called "omnibus law" in October 2020, that promised to eliminate red tapes and streamline the country's investment process.

${ }^{25}$ Most FDIs to Indonesia in the last few years have been channelled to non-manufacturing sectors. Only at number 10 of the destination of FDIs in Indonesia does a manufacturing sector feature, however, this is the automotive industry.

${ }^{26}$ World Integrated Trade Solution: https://wits.worldbank.org/

27 Jefriando M, Widiant S (2021). Indonesia may allow private sector to buy and distribute vaccines. 14 January 2021: https://www.reuters.com/article/us-health-coronavirus-indonesia-vaccine-idUSKBN29J1ET

${ }^{28}$ Bachtiar NS, Nurlaela N (2014). Sejarah perkembangan produksi vaksin di Bio Farma, Indonesia [History and development of vaccine production in Bio Farma, Indonesia]. Immunization program in Indonesia: History and Development. Jakarta.

29 Indonesia is importing China's Sinovac Biotech Ltd COVID-19 vaccine. Sinovac will also ship raw material for 45 million doses, which Indonesia's state pharmaceutical firm Bio Farma will process locally. Besides Sinovac, the Government has orders with at least three other vaccine suppliers, including AstraZeneca Plc. Indonesia may allow companies to procure their own COVID-19 vaccines for their staff, to further reduce the economic burden on the state. However, this may discriminate those from lower-incomes.

30 Dr Ahd Hamidi, bioprocess technologist: http://dx.doi.org/10.2471/BLT.19.031219
} 
formed partnerships with international players for the development of more niche vaccines to supply the global market, e.g. co-operation with Australia's Murdoch Children's Research Institute in the development of a rotavirus vaccine. ${ }^{31}$ However, the long-term challenges in the inflexible labour market needs to be addressed to improve vaccine manufacture. Schools and colleges have to produce graduates with better skills, to match with industry needs. Additionally, Indonesia's export-oriented sectors not only need an FDI-friendly policy, but also progressive Government policies to attract manufacturing investors (Ginting, 2019).

\section{Thailand}

The state enterprise Government Pharmaceutical Organization (GPO) manufactures vaccines in Thailand (WHO, 2011: 24). Data from 2016 shows that the organisation produces drugs at two government-owned factories. ${ }^{32}$ Thailand has held vaccines capabilities in small scale settings since 1953, with the set-up of a BCG vaccine production at Queen Saovabha Memorial Institute (QSMI). Since 2010, BIOVALYS ${ }^{33}$ biopharmaceutical company focuses on finding partners that are quality vaccine manufacturers.

\section{Capital support and framework}

Procurement of vaccines and the immunisation programme is financed mainly by the Government, i.e. the National Health Security Office (NHSO) through its tax payments to primary care facilities. This includes distribution of vaccines to all health care facilities in the universal health coverage (UHC) scheme (Coe \& Gergen, 2017: 10). The UHC scheme finances all vaccines under the EPI, which helps ensure its long-term financial sustainability. ${ }^{34}$

Government-use licences on vaccines (ARVs) disseminated are issued under the authority of the Ministry of Health (MoH) (WHO, 2011: 39). The National Program for Immunization produces and distributes vaccines for its Expanded Program of Immunization (EPI), but is fiscally constrained from adding new vaccines. New products are subject to a long and complicated approval process before being included in the program, or are only available in the private market (Milken Institute, 2016: 9). However, the one-sided health financing system by the NHSO comes with its own dangers. In the event of an economic downturn, the tax base could be squeezed, threatening health financing (Coe \& Gergen, 2017: 12). The costly vaccine procurement will make vaccines generally prohibitive to the average consumer (Milken Institute, 2016: 7).

Public-private partnerships (PPPs) are vital for Thailand to accelerate vaccine development and production. It includes seeking appropriate partners within and outside the country, given that private firms in Australia, India, Indonesia, and some other countries in the region are experienced in the field of vaccine development and production. Although PPPs are already

\footnotetext{
${ }^{31}$ Indonesia is becoming a global vaccine player, but so is China. 8 April 2015:

https://www.manufacturingchemist.com/news/article_page/Indonesia_is_becoming_a_global_vaccine_player_but so is China/107395

32 "Our Factories". Government Pharmaceutical Organization (GPO). Archived from the original on 5 February 2016: http://ggtcf.blogspot.com/2019/04/government-pharmaceutical-organization.html

${ }^{33} \mathrm{https}: / /$ www.biovalys.com/our-company/

34 Thailand's New National Vaccine Strategy. 28 June 2011: https://www.nbr.org/publication/thailands-newnational-vaccine-strategy-building-capacity-accelerating-production/
} 
addressed as part of the new National Vaccine Strategy, ${ }^{35}$ there are very few cases of such partnerships at the initial phase of the R\&D process. One example is GPO-Mérieux, the joint venture between the Thai government and Sanofi-Pasteur, to manufacture innovative vaccines that meet regional needs. This PPP is unique in the ASEAN region. Sanofi-Pasteur's Japanese encephalitis vaccine (JEV) has been developed through regional clinical development and transfer of all manufacturing steps after bulk vaccine production to its Thai facility (Brückler, 2013). Also, Biovalys has successfully joined QSMI, BioNet-Asia Co., Ltd, and Liaoning Cheng Da Bioechnology Co Ltd (CDBIO) to manufacture rabies vaccine (TRCS CPRV) and supply in Thailand and ASEAN countries.

\section{Pharma growth and vaccine access}

Thailand ranked $7^{\text {th }}$ in the top 10 investor economies by FDI stock in 2013 and 2017 (UNCTAD, 2019: 71). The $131 \%$ growth in outward FDI stock from Thailand to LDCs was due to the country's investment in ASEAN economies, in particular in Myanmar (USD4.2 billion in 2017) and the Lao People's Democratic Republic (USD3.4 billion) (UNCTAD, 2019: 69).

Thailand is not vaccine self-sufficient, but is putting plans in place to be. Thailand embarked on a National Vaccines Strategy in 2011, aiming not just to become self-sufficient but also to meet regional needs of vaccines for ten diseases (Brückler, 2013). The plan includes recommendations for human resources, infrastructure development, and domestic production. If production succeeds, Thailand would be able to produce most of the essential vaccines for use in their EPI system. In 2020, the EPI programme added Rota vaccine for children 2- and 4months of age. ${ }^{36}$ However, the country produces only two of the vaccine antigens scheduled in the EPI - although data is only available from $2011 .{ }^{37}$

Siam Bioscience ${ }^{38}$ is the first and only biopharmaceuticals manufacturer in Thailand. It is owned by the Thai king's vast business holdings. The group, established since 2009, consisted of two major companies: Siam Bioscience Co Ltd. and Apexcela Co Ltd. Apexcela focuses on sales, marketing, and distribution of Siam Bioscience products, including business developments aiming to build partnerships both in Thailand and worldwide. In 2017, Siam Bioscience Group expanded business further by establishing two subsidiaries - one based in Cuba. ${ }^{39}$ Thailand is planned to be the Oxford University COVID-19 vaccine production base for the ASEAN region. Out of the 1 trillion baht (USD33 billion) allocated to public health in the 2021 fiscal budget, 40 billion baht (USD1.3 billion) has been set aside to for COVID-19 related measures,

\footnotetext{
${ }^{35}$ Dengue, diphtheria, tetanus, pertussis, mumps, measles, encephalitis, polio, hepatitis B, and tuberculosis. 36 Thailand Expanded Programme on Immunization 2020. 5 October 2020: https://www.biovalys.com/healthupdates-and-news/thailand-expanded-programme-on-immunization-

2020/\#: :text=Thailand\%20Expanded\%20Programme\%20on\%20Immunization\%20(EPI)\%20has\%20included\%2 0BCG\%2C,and\%204\%20months\%20of\%20age.

37 Thailand's New National Vaccine Strategy - Building Capacity, Accelerating Production. Interview with Yot Teerawattananon. 28 June 2011: https://www.nbr.org/publication/thailands-new-national-vaccine-strategybuilding-capacity-accelerating-production/

$38 \mathrm{https}: / /$ www.siambioscience.com/?lang=en

39 Inno Biocosmed Co., Ltd. and Abinis Co., Ltd. (the joint venture company with CIMAB (Cuba) for R\&D, manufacturing, and commercialisation of mammalian cell culture derived focus on exportation).
} 
such as production of a vaccine. ${ }^{40}$ In February 2021, Siam Bioscience became one of 25 companies chosen by AstraZeneca to become its manufacturer of the COVID-19 vaccine. ${ }^{41}$

\section{Vaccine exports and imports}

Thailand's pharmaceutical export value was USD474.5 million in 2019. It is forecast to rise to USD502 million by 2024 with a five-year CAGR of $3.1 \%$ in local currency terms, and $1.1 \%$ in US dollar terms ${ }^{42}$ Special economic zones (SEZs) promote FDI in health-related activities. These zones prioritise manufacturing of medical devices and pharmaceuticals (OECD, 2020: 14). The Industrial Estate Authority of Thailand (IEAT), ${ }^{43}$ a state-enterprise under the Ministry of Industry, has established 12 special IEAT "free trade zones" reserved for industries manufacturing exclusively for export. ${ }^{44}$ Besides Thailand, GPO markets its products in Nigeria, Ghana, Bhutan, Somalia, Myanmar, Sri Lanka, Malaysia, Cambodia, and Vietnam. ${ }^{45}$ GPO will produce the anti-retroviral (HIV vaccine) Efavirenz - sold under the brand name Sustiva, amongst others - after receiving WHO approval. GPO's product costs 180 baht (USD 6) per bottle of thirty $600 \mathrm{mg}$ tablets. The imported version retails for more than 1,000 baht (USD 33) per bottle. GPO will devote $2.5 \%$ of its manufacturing capacity to make 42 million Efavirenz pills in 2018, allowing it to serve export as well as domestic markets. The Philippines alone will order about 300,000 bottles of Efavirenz for 51 million baht (USD1.7 million). ${ }^{46}$

\section{Since 2010, GPO-MBP, a joint venture between the Government Pharmaceutical}

Organization and Sanofi Pasteur, supplied approximately 800,000 doses of seasonal influenza vaccine by formulating and filling imported bulk, and the remaining 1.3 million doses were imported as finished products (Pitisuttithum \& Wirachwong, 2019). Thailand is now focusing on local production possibilities rather than importation of new vaccines, with support from Gavi (Makenga et al., 2019).

\section{Positive spillover effects}

Thailand has a bold vision for growth, however there is no evidence on positive spillover effects.

\section{Skills development}

For the $2009 \mathrm{H} 1 \mathrm{~N} 1$ influenza pandemic, technology transfer was an important factor. The nonprofit PATH International provided licensure dossier preparation assistance, as well as

\footnotetext{
40 Oxford picks Thailand as production base for Covid-19 vaccine. 19 October 2020:

https://www.nationthailand.com/news/30396412?utm_source=category\&utm_medium=internal_referral 41 Siam Bioscience was selected by AstraZeneca. 18 February 2021: https://www.thaipbsworld.com/siambioscience-was-selected-by-astrazeneca/

42 Thailand Pharmaceutical Exports Expected To Demonstrate Growth As Domestic Industry Expands. 4 September 2020: https://www.fitchsolutions.com/corporates/healthcare-pharma/thailand-pharmaceutical-exportsexpected-demonstrate-growth-domestic-industry-expands-04-092020\#: :text=Thailand\%27s\%20pharmaceutical\%20 export\%20value\%20was, 1.1\%25\%20in\%20US\%20dollar\%2 Oterms

${ }^{43} \mathrm{https}: / /$ www.ieat.go.th/en

44 THAILAND: FOREIGN INVESTMENT: https://santandertrade.com/en/portal/establishoverseas/thailand/foreign-investment

${ }^{45}$ Company Overview - Government Pharmaceutical Organization: http://www.intergpomed.com

${ }^{46}$ Wipatayotin A (2018). "Thailand gets nod to make HIV/Aids drug". Bangkok Post. 3 November 2018.

https://www.bangkokpost.com/thailand/general/1569426/thailand-gets-nod-to-make-hiv-aids-drug
} 
production and process development (PATH, 2018: 7). A sub-license agreement with made with WHO to obtain Russian live attenuated influenza vaccine (LAIV) technology from the Institute of Experimental Medicine (IEM) ${ }^{47}$ in Saint Petersburg, Russia (Pitisuttithum \& Wirachwong, 2019). IEM provided methodological support to the scientific team in Thailand.

The 2018 Smart Visa programme is a more recent method set-up to attract high-skilled experts, investors, and employees of foreign start-ups in high-tech medical devices to Vietnam (OECD, 2020: 14). However, there is no evidence available to show how successful this has been for vaccine manufacture.

Manufacturing makes up $42.9 \%$ of main invested sectors. With an increased recognition that macroeconomic liberalisation and an economy driven by manufactured exports would not ensure sustainable growth, Thai policy makers and firm managers belatedly shifted their attention to technology matters and human resource development, on ways in which FDI can be leveraged more strongly to support manufacture (IMF, 2002: 11). However, there is no data available for vaccine manufacture. Also, retaining vaccine know-how is an issue: employee turnover in the health-care industry is high. Some work on a volunteer basis, while others receive low salaries.

\section{Vietnam}

Vietnam's domestic manufacturing has historically been successful, and it is practically self-sufficient. The first vaccine produced in Vietnam was oral polio vaccine (OPV) in the early 1960s, which contributed to polio eradication in Vietnam in 2000 (Pagliusi et al., 2014). Vietnam eliminated neonatal tetanus in 2005, and has controlled measles and hepatitis B spread (Pagliusi et al., 2014). Since 2006, there have been no whooping cough fatalities. Vietnam has been conservative in prioritising new vaccines (ThinkWell, 2017: 5). However, the Expanded Program on Immunisation (EPI) was launched in Vietnam in 1985 with six vaccines, and by 2015 was expanded to 12 vaccines. ${ }^{48}$ All EPI vaccines used in Vietnam are domestically produced, with the exception of two imported products.

Manufaturing capabilities are shared over four Government-backed institutes, using equipment and technology that meets Current Good Manufacturing Practice (cGMP)-WHO standards, with each institute building up its own specialties (Nhan Dan, 2020):

- Company for Vaccine and Biological Production No.1: The state-owned limited company VABIOTECH was originally established by the Vietnamese Minister of Health in March 2000. It is the biggest vaccine manufacturer and supplier for the National EPI in Vietnam. VABIOTECH currently produces vaccines against hepatitis $A$, hepatitis $B$, Japanese encephalitis, and cholera;

- Da Lat Pasteur Vaccines Company Ltd: the Dalat Pasteur facility was incorporated as the Dalat Pasteur Vaccines Company Limited (DAVAC) in 2010;

\footnotetext{
47 http://www.iem.cas.cz/en/

48 Tuberculosis, diphtheria, pertussis, tetanus, hepatitis B, measles, polio, Japanese B encephalitis, cholera, typhoid, rubella, and Haemophilus Influenza Type b (Hib).
} 
- MoH's Centre for Research and Production of Vaccines and Biology: POLYVAC has been prequalified by WHO and is at the vanguard of the country's efforts to improve the quality and targeting of its products, and

- Institute of Vaccines and Medical Biologicals: IVAC has been producing vaccines in Vietnam for several years. Since 2010, IVAC has been working to develop and license vaccines against both seasonal and pandemic influenza. This will be a critical achievement because Vietnam is uniquely vulnerable to A/H5N1 (Regan, 2018).

However, as a result of improvements in health status, the country is undergoing several epidemiological transitions. Obstacles that pharmaceutical manufacturers must face when launching new products into Vietnam's pharmaceutical marketplace are listed below:

- the health system is facing a number of challenges, not least of which is the widespread withdrawal of external funding support for continuing health care activities (WHO, 2017: 1);

- comparing prices for domestic vaccines versus alternative international commercial products is complicated by the way in which the MoH fixes prices for domestic vaccine products ${ }^{49}$;

- the challenge of establishing reliable independent financing for the EPI vaccines (i.e. secure $100 \%$ funding from Government of Vietnam sources) will remain a critical issue for coming years that will constrain the available $\mathrm{MoH}$ budget to work on non-priority diseases, such as seasonal influenza (WHO, 2017: 16);

- establishing a system for post-marketing surveillance will be an important challenge for obtaining PQ status (WHO, 2017: 19);

- the pricing structure negatively impacts the amount of resources available for R\&D, and for reinvestment into company infrastructure (for example, to maintain GMP status) (WHO, 2017: 21). Neither POLYVAC nor the other state-owned operations have negotiating power to change the vaccine pricing scheme, and these policies pose challenges for corporate financial management;

- further adaptations to meet WHO global export standards are necessary, such as the WHO certification of the Vietnamese NRA and the GMP certification of production sites, which are time- and resource-intensive changes (Brückler, 2013);

- a major challenge is its high logistics costs, owing to under-developed transport infrastructure and inadequate logistics facilities. Higher logistics costs tend to bring down the profitability of import, export, transportation and delivery services within the country. This implies a higher demand for cost-effective and efficient logistics services in Vietnam (Locus Bulletin, 2019), and

- the EPI still faces challenges, including a shortage of medical staff majoring in immunisation in the grassroots level, inadequate vaccine supply in some localities,

\footnotetext{
49 Prices for domestic vaccines produced by POLYVAC, VABIOTECH, and IVAC are dictated by MoH policy, and have remained largely static since 2008 (WHO, 2017: 17). Pricing and financing issues continue to be an important deterrent for more pro-active promotion of influenza vaccine uptake.
} 
reduced funds and declining international aid, as well as poor public awareness of the importance of vaccination..$^{50}$

\section{Capital support and framework}

Vietnam is a rapidly developing country. Vietnam was declared a middle-income country in 2009 by the OECD. Countries like Vietnam transitioning to middle-income status increasingly bear the cost of both existing and new vaccines (Jit et al., 2015). Support from Gavi had allowed Vietnam to move forward in expanding their package of vaccines, and reaching remote areas their exit between 2016 and 2020 will leave a gap in financing (ThinkWell, 2017: 5). The Government budget for immunisation confirmed in 2017 guarantees increased domestic financing for both vaccines and the cold chain through to $2020 .{ }^{51}$

The National Regulatory Authority (NRA) of Vietnam reached WHO international standards for vaccine regulation in June 2015. The Drug Administration of Vietnam (DAV) issues a new drug registration within 180 days of an application being submitted. This makes the process much quicker than in the US and UK, although it is in line with other countries in Southeast Asia. ${ }^{52}$ By law, an extension to the current marketing authorisation should be issued within three months from the receipt of a complete application dossier. ${ }^{53}$

The combined 5-in-1 vaccine to protect against DPT, HepB and Hib (Quinvaxem - has been sponsored free of charge and measles-rubella (MR) vaccine (WHO, 2017: 5). In 2015, Vietnam was the only country in the world running two vaccination systems: the EPI and the non-EPI vaccination service. The Government requested relevant authorities draw up a plan towards a united vaccination programme in the country by 2020 . Initially, the Ministry of Finance developed a decree to define prices for the EPI and non-EPI vaccination services (Nhan Dan, 2020).

\section{Pharma growth and vaccine access}

A recent GDP growth statistics report states that Vietnam is the fastest growing world economy, with a growth rate of $7.31 \%$ in 2019 . It has surpassed the growth rate of other Asian economies including India and China, which stand at $4.5 \%$ and $6 \%$ CAGR respectively (Locus Bulletin, 2019). The DAV states that the pharmaceutical market of Vietnam was worth USD5.2 billion in 2020 , with the growth rate of $12 \%$ per year. ${ }^{54}$ Market research firm

\footnotetext{
50 Vietnam becomes vaccine self-sufficient. 15 December 2012:

http://dtinews.vn/en/news/017002/26660/vietnam-becomes-vaccine-self-sufficient.html

51 Anuradha Gupta, Deputy CEO of Gavi, the Vaccine Alliance. 29 September 2017:

https://www.gavi.org/vaccineswork/prioritising-prevention-vietnams-vaccine-success-story

52 For a new vaccine, or where the safety and effectiveness report of the drug is not available or insufficient, the DAV will grant a marketing authorisation with a three-year term. Within 12 months before the expiration date of the current marketing authorisation, the marketing authorisation holder may apply for an extension - Vietnam's Pharmaceutical Market Value to Hit \$8 Billion by 2020: https://drug-dev.com/vietnams-pharmaceutical-marketvalue-to-hit-8-billion-by-

2020/\#: :text=The\%20pharmaceutical\%20market\%20in\%20Vietnam, research\%20and\%20consulting\%20firm\%2 0GlobalData

53 Regulatory, Pricing and Reimbursement Overview. 30 May 2020: https://pharmaboardroom.com/legalarticles/regulatory-pricing-and-reimbursement-overview-vietnam/

54 VietnamCredit: Vietnam's pharmaceutical market worth more than USD 5 billion. 19 August 2020: https://www.febis.org/2020/08/19/vietnamcredit-vietnam-s-pharmaceutical-market-worth-more-than-usd-5billion/\#: :text=Market\%20research\%20firm\%20IBM\%20said,50\%20per\%20person\%20in\%202020.
} 
IBM predicts that the size of Vietnam's pharmaceutical industry may reach USD 7.7 billion in 2021 and USD16.1 billion in 2026. Vietnam has benefited from progressive Foreign Direct Investment (FDI) policies. Inflows to Vietnam rose marginally, reaching an all-time high of USD16 billion, with robust inflows into manufacture (Ginting, 2019; UNCTAD, 2020: 43). Almost $68 \%$ of the total FDI capital was invested in the manufacturing industry (Locus Bulletin, 2019). The primary factor contributing to this massive leap in Vietnam's economic growth is the amount of FDI coming in from investors around the world, especially the Republic of Korea, Japan, and Singapore. Another driving force behind Vietnam's growing investment popularity is the country's collection of free trade agreements (FTAs), such as the Comprehensive and Progressive Agreement for Trans-Pacific Partnership with Canada, and the 2018 EU-Vietnam FTA with European countries (Locus Bulletin, 2019; OECD, 2020: 16).

Currently Vietnam has a small, but relatively impressive portfolio of vaccines and vaccine research projects. In late February 2014, Vietnam drew wide attention from the media, announcing its success in producing a diarrhoea vaccine for children for the first time. The successful production of Rotavin-M1 vaccine has helped Vietnam to become the fourth country in the world and second in Asia able to produce vaccines against rotavirus (Nhan Dan, 2020). According to the National Product Development Programme for human vaccine, Vietnam was predicted to produce and commercialize at least 7 vaccines by $2020 .{ }^{55}$ The country is moving towards wiping out measles, and there are plans for development of a 6 -in-1 vaccine to protect from diphtheria, whooping cough, tetanus, polio, influenza type B and Hepatitis B..

\section{Vaccine exports and imports}

Since 2012, Vietnam has been reporting trade surpluses more frequently, as exports growth have been stronger than imports. In 2017, trade deficits were recorded with South Korea, China, Taiwan, Thailand, Singapore and Argentina. Vietnam recorded trade surpluses with the United States, Netherlands, Hong Kong, United Kingdom, United Arab Emirates, and Austria. ${ }^{56}$

Vietnam is ahead of most other Asian countries in this respect since it has always promoted an export-oriented growth strategy. A progressive FDI policy supports that. Geography helps too. Vietnam exports more to China than any of its competitors in part because it is located right next door (Ginting, 2019). It is expected that Vietnam will continue to develop vaccines catering to its domestic market before developing the capability to produce vaccines for export purposes, such as those for hepatitis B and human papillomavirus (HPV). Therefore, Vietnam will, therefore, continue to have a negative vaccine trade balance (EVBN, 2014: 32)

- VABIOTECH now imports and provides some vaccines and biological products to meet the market's demand such as: Mumps, Rubella, Meningococcal, and Varicella at favourable prices. In February 2021, the Deputy Minister of Health signed a decision to approve the conditional import and use of the vaccine developed by AstraZeneca and Oxford University. This is the first COVID-19 vaccine allowed for usage in Vietnam, which

\footnotetext{
55 Vietnam makes efforts to produce 6 in 1 vaccines. 23 December 2015: https://english.vtv.vn/news/vietnammakes-efforts-to-produce-6-in-1-vaccines-20151227110300801.htm

56 Vietnam Balance of Trade: https://www.fxempire.com/macro/vietnam/balance-of-trade
} 
will be imported under the regulation on "emergency cases of disease prevention." 57 This is a lesson learned from the worldwide $\mathrm{A} / \mathrm{H} 1 \mathrm{~N} 1$ pandemic struck in 2009, when Vietnam waited for more than a year to receive imported vaccine (Regan, 2018). Vietnam requires all imported biological products and new batches of vaccines to undergo quality testing by the National Institute for Control of Vaccine and Biologicals which 'does not have the capacity to effectively conduct such tests'. Therefore, these requirements only serve to delay the time needed to launch pharmaceutical products in Vietnam (EVBN, 2014: 41).

\section{Positive spillover effects}

There is limited evidence of positive spillover effects due to local vaccine manufacturing. Improving Avian Influenza-Highly Pathogenic (HPAl) control in commercial poultry sector could have positive spillover effect on the epidemiological situation of the disease in native and backyard poultry. ${ }^{58}$ The only evaluation of Vietnam's EPI using two separate approaches shows that it has made a substantial impact on mortality, and is very likely to be cost-effective (Jit et al., 2015).

\section{Skills development}

All four national factories have qualified staff to research, and produce vaccines with international standards for the EPI (Nhan Dan, 2020). For example, DAVAC specialises in technology transfer and support, scientific research and staff training at home and abroad. In 2016, the MR vaccine was produced in Vietnam by POLYVAC under a technology-transfer project launched by the Japan International Co-operation Agency (JICA). Vietnam also has a good education system considering its level of development capable of producing an ample quantity of skilled labour that can participate in a wide range of manufacturing (Ginting, 2019). PATH supported IVAC as it worked to develop influenza $A / H 1 N 1$ and $A / H 5 N 1$ pre-pandemic vaccine candidates as well as a low-cost, seasonal influenza vaccine candidate. This work built on previous efforts in which PATH and WHO helped IVAC ready its vaccine production facility for influenza vaccine manufacture and clinical development. PATH has also worked closely with Vietnam's $\mathrm{MoH}$ to build a supportive environment for influenza vaccine development and use. PATH also helped VABIOTECH obtain a commercial manufacturing license for a cell line suitable for influenza virus vaccine production, conducted technical trainings, and purchased equipment and supplies to support development of the cell based GMP process (PATH, 2018: 7).

\section{Brazil}

The Brazilian vaccine manufacturers' perspective is very positive, because it relies on the National Immunization Program (PNI), which is considered one of the best and most complete

\footnotetext{
57 Health Ministry approves first COVID-19 vaccine in Vietnam. 2 February 2021: https://tuoitrenews.vn/news/society/20210202/health-ministry-approves-first-covid19-vaccine-invietnam/59118.html

58 Modeling the effectiveness of avian influenza vaccination strategies in Vietnam - evaluation of the added value of day-old chick vaccination in hatcheries:

https://umr-astre.cirad.fr/content/download/5568/41770/version/2/file/EVACs_Vietnam_summary.pdf
} 
among emerging countries (Homma, 2009). There are two main actors focused on human health (Homma, 2009):

- The Immunobiological Technology Institute (Bio-Manguinhos), from the Oswaldo Cruz Foundation/Fiocruz $(\mathrm{MoH})$, which develops and produces vaccines (such as: DTP + Hib, meningitis AC, OPV, triple viral, yellow fever), and biopharmaceuticals (erythropoietin, interferon alfa $1 \mathrm{~b}$ ), especially for the national health programmes, and

- The Butantan Institute (São Paulo State laboratory), also in charge of developing and producing vaccines (DTP, DT, HBV, influenza) for the public system, and immune serum (anti-snake, anti-toxin).

In spite of a significant and increasing role for some Brazilian universities, research institutes and companies, the number of patents for vaccines in the country is still low, indicating the need for a national strategy supporting innovation and technological development. Like other developing countries, the main challenge for Brazil and other is to accelerate and streamline the procedures of their national patent offices (the National Institute of Industrial Property [Instituto Nacional de Propriedade Industrial, INPI] in the case of Brazil) (Possas et al., 2015). Brazil local companies has been stuck in the grind of generics manufacturing ${ }^{59}$, unable to produce notable advancements in vaccine $R \& D$ (Parrish, 2020). However, the industry could be approaching a turning point due to the COVID-19 epidemic.

\section{Capital support and framework}

The research, development and production of immunobiologicals in Brazil, especially vaccines for human use, is mainly supported by Governmental institutions linked to the Ministry of Health $(\mathrm{MoH})$ as part of a strategy that prioritises the public sector for access to vaccines and other biologicals that are regarded essential for the population (Homma, 2009). However, recent research shows the need for progress in the Brazilian national strategy to link domestic production, technological capacity-building, and innovation in the vaccine sector to help guarantee universal access to health in Brazil (Gadelha et al., 2020).

Both Institutes enjoy a de facto monopoly on the large Brazilian public market, prices are set by the $\mathrm{MoH}$, and track the prices charged for similar vaccines by the PAHO Revolving Fund or UNICEF (Milstien et al., 2007). The international non-profit PATH assisted Instituto Butantan's efforts to achieve WHO PQ status ${ }^{60}$ of its seasonal, trivalent inactivated influenza vaccine, which is already licensed for use in Brazil (PATH, 2018: 7). However, investment in Brazil remains risky

\footnotetext{
59 The pharma market in Brazil is divided between generics and branded medicines. According to Sindusfarma, the Brazilian Ministry of Economy registered 418 pharma manufacturing plants in the country in 2018. EY estimates that nearly half of the industry's revenue is concentrated in its top 10 companies. Of those 10, six are Big Pharma companies and the other four are local. Generally speaking, while Big Pharma companies control the market for branded medicines in Brazil, almost all of the local companies stick with the generics market. Local companies have been successfully managing in this environment, but it is not a very easy market to play in (Parrish, 2020). With access to free health care guaranteed by SUS, Brazil's Government and hospitals have a $30 \%$ portion of the local low-cost drug market, while the other $70 \%$ of drugs are sold through commercial pharmacies.

${ }^{60} \mathrm{PQ}$ enables a vaccine to be available for procurement by United Nations agencies and Gavi for use in lowresource countries and is key for reaching global markets.
} 
because of some negative factors, including cumbersome and complex taxation, bureaucratic delays, as well as heavy and rigid labour legislation. ${ }^{61}$

\section{Pharma growth and vaccine access}

Brazil is one of the fastest growing global economies. Brazil is not only being the biggest country in Latin American but also the most influential. It is the second most attractive BRIC (Brazil, Russia, India, China) nation ${ }^{62}$ in the eyes of the pharma industry (Chhabara, 2010). ${ }^{63}$ Brazil is an attractive market for international investors due to several factors: a domestic market of nearly 210 million inhabitants, availability of easily exploitable raw materials, a diversified economy that is less vulnerable to international crises, and a strategic geographic position that allows easy access to other Latin American countries.

It enjoyed huge economic growth in the first half of 2010 emerging from the downturn faster than its closest Latin American rivals in terms of demand for pharmaceuticals (Bates, 2011). According to Chamber for Pharmaceutical Market Regulation (CMED) data, the Brazilian pharmaceutical market's turnover in 2017 was approximately BRL69.5 billion (approximately USD22 billion), or 9.4\% nominal growth over the year 2016 (Gadelha et al., 2020).

The Brazilian pharma market outperformed the Latin American average in Q1 of 2020 with a growth of $8.2 \%$ in real terms (inflation adjusted), according to IQVIA. As a general rule, the pharma sector in Brazil has never been a major contributor to the world's advancements in R\&D, save for one exception - vaccines (Parrish, 2020).

The Instituto de Tecnologia em Fármacos Farmanguinhos is currently the largest official pharmaceutical laboratory linked to the $\mathrm{MoH}$. Farmanguinhos plays a strategic role by acting as a regulator of market prices of antiretroviral vaccines. Thus, the Institute stands out in the struggle for cost reduction, which contributes to more Brazilians have access to public health programmes. Currently, the institute can produce more than 50 different types of medicines, according to the needs of SUS.

Bio-Manguinhos (Immunobiological Technology Institute) is a unit of the Government-funded Oswaldo Cruz Foundation (Fiocruz). In October 2013, Fiocruz announced that it was going to develop an affordable bivalent measles and rubella (MR) vaccine with the support of the Bill \& Melinda Gates Foundation. The Brazilian MoH allocated funds to support this plan, including USD727 million for the construction of a plant at the Bio-Manguinhos site to produce the vaccine. In December 2020, an agreement with the Government of the State of Rio de Janerio was announced for the Industrial Complex of Biotechnology in Health (Cibs) to be built, in the Industrial District of Santa Cruz, Rio de Janeiro. The new plant aims to enable the production of new vaccines, such as the bivalent vaccine (for measles and rubella), clinical studies of

\footnotetext{
${ }^{61}$ https://santandertrade.com/en/portal/establish-overseas/brazil/foreign-investment

62 These four developing countries are at a similar stage of newly advanced economic development, on their way to becoming developed countries.

63 The pharma sector in Brazil underwent radical change as the political restructuring, deregulation, and decentralisation of power that followed the end of the military coup in 1988. This resulted in a breakdown of stateled development and production. The re-democratisation process led to a new federal constitution that introduced state-funded healthcare for all: the first initiative of its kind, not only in Brazil but also across the BRIC nations. The integrated/unified health system, known as SUS, focused on prevention offering comprehensive cover providing a basic level of care to all, in addition to more costly treatments such as antiretroviral therapy for HIV (Bates, 2011).
} 
which were recently concluded by Bio-Manguinhos, and meningococcal $\mathrm{C}$, which is in an advanced stage of studies phases II/III, in addition to new vaccine presentations from the Institute's portfolio (number of doses/bottle), to meet different needs of the health system. ${ }^{64}$ In January 2021, Fiocruz officially submitted the application to register the COVID-19 vaccine to ANVISA, which will allow the Oxford-AstraZeneca immuniser COVID-19 vaccine across the country, which will be distributed through the Ministry of Health's PNI.

\section{Case study: An innovative moderate volume public sector manufacturer partnering with an MNC (BioManguinhos and Butantan, Brazil- Cuba)}

Positives: The Brazilian manufacturers, BioManguinhos and Butantan, have invested in R\&D, have knowledge of intellectual property concerns, are supported by a well-functioning national regulatory authority, and are together providing the majority of Brazil's public sector vaccines. This success has been based on a long history of manufacturing, plus a strong Government interest in strategic planning. Although only BioManguinhos currently produces PQ products (yellow fever vaccine and meningitis AC polysaccharide vaccine - in collaboration with Cuba's Findlay Institute, another example of South-South coopera-tion), both have attracted the attention of large vaccine MNCs, who have transferred vaccine production technology starting from filling of imported bulk vaccines. BioManguinhos has had such an agreement in force with GSK for many years for filling of oral poliovirus vaccine, and recently concluded one for measlesmumps-rubella vaccine. Also through a GSK agreement, they have progressed to full scale production of Hib vaccine, and will shortly commence filling of imported pneumococcal conjugate bulks as a step towards a full technology transfer of that vaccine. Sanofi Pasteur has had a similar arrangement with Butantan, which has now started full scale influenza vaccine production. The advantages of such agreements are that they allow the country to benefit from a new vaccine technology sooner, and will eventually result in national ownership of the technology.

Challenges: Disadvantages are that the prices may be higher than could eventually be attained by these national manufacturers, and they are not able to be offset by export sales, which are controlled by the MNC.

\section{Vaccine exports and imports}

The country has actively exported yellow fever vaccine since 2002 and meningitis AC vaccine since 2007, having covered more than 60 nations (Homma, 2009). Once Butantan could produce up to 180 million DTP Triple vaccines (diphtheria, tetanus, pertussis) (or its combinations) per year, it began exports (Raw \& Higashi, 2008: 160).

As a result of Government support, $83 \%$ of the vaccines required in 2007 were provided by national vaccine producers and only $17 \%$ were imported, mainly to reference centres for special vaccines that were used for special patients. Perspectives have positively increased due to the Government's policy of making internal investments, not only to avoid the external dependence of products for public health, but also to strengthen the Brazilian industrial sector related to biotechnology (Homma, 2009).

According to the Brazilian Constitution, plasma and its by-products cannot be sold - the plasma is therefore exported for processing as an alternative (Raw \& Higashi, 2008: 168). Nucleic acid-based technologies support fast and flexible vaccine development and production (Rauch et

\footnotetext{
${ }^{64}$ https://uk.finance.yahoo.com/news/global-meningococcal-vaccine-market-brand-111900272.html
} 
al., 2018). Since all vaccines can be produced using the same basic components, manufacturing of several vaccines can take place in one established facility cutting both costs and time of vaccine production dramatically.

Imports of finished products, semi-finished products, vaccines, blood products, and other pharmaceutical products reached USD7.3 billion - an increase of $1.4 \%$ compared to the previous year. $^{65}$

However, with Brazil relying on generic manufacturing to supply its demand for lower cost drugs, the industry has become linked to API imports from India and China. Ernst \& Young $(E Y)$ and PricewaterhouseCooper (PwC) both estimate that Brazil currently imports about $90 \%$ of its APIs, leaving the supply chain vulnerable to disruptions in the quantity and quality of its drug ingredients (Parrish, 2020). So far, Brazil has not experienced any supply disruptions during the COVID-19 pandemic, but the situation has exacerbated concerns about shortages, and increased pressure on the industry and Government to find solutions. ${ }^{66}$

\section{Positive spillover effects}

There is limited evidence on positive spillover effects of local vaccine development. Only Baptista et al. (2006) estimated a $61.6 \%(95 \% \mathrm{Cl} 12.8 \%, 83.1 \%)$ risk reduction in studies of spillovers in households with individuals diagnosed with pertussis who were vaccinated versus those unvaccinated for pertussis (the vaccine efficacy for infectiousness).

\section{Skills development}

Development of vaccines through technology transfers has been essential to the country's universal immunisation programme (IFPMA, 2015: 7). Five partnerships which supported technology transfer in Brazil in $2006^{67}$ included agreements for the transfer of knowhow, but no licences for patents rights. Conversely, an agreement for the transfer of dengue vaccine technology, from the US National Institutes of Health to Butantan in Brazil, included a licence for patent rights but no explicit authorisation for the transfer of knowhow. PATH also provided Butantan with guidance on improving its quality management system and developing a pharmacovigilance system, and also provided support for the development of a pre-pandemic inactivated influenza A/H7N9 vaccine candidate (PATH, 2018: 7).

Much of 2010 was spent forging close links with the biotechnology sector and continued open dialogue with the Federal Medicine Council (Conselho Federal de Medicina, CFM) to foster ties between industry and healthcare professionals, with the aim of developing patient and public health initiatives (Bates, 2011). The creation of the Health Economic-Industrial Complex (HEIC) in the early 2000s has guided and amplified biotechnological research and pharmaceutical, vaccine and diagnostics production, and has helped to create jobs and national economic growth (WHO, 2011: 39). Butantan has developed its own technology and commands production. This type of control required designing and building new production

65 Profile of the pharmaceutical industry and relevant sector aspects: https://sindusfarma.org.br/uploads/Publicacoes/Perfil_IF2020_ING.pdf

66 Eliane Kihara, a partner with PwC.

${ }^{67}$ Milstien JB, Gaulé P, Kaddar M (2007). Access to vaccine technologies in developing countries: Brazil and India. Vaccine, 25(44), 7610-7619: http://dx.doi.org/10.1016/j.vaccine.2007.09.007 
plants. Butantan constantly teaches Brazilian builders what is needed, such as filtered air to maintain sterility and even teaches Brazilian companies to produce equipment that had always been imported (Raw \& Higashi, 2008: 157).

\section{Cuba}

Cuba currently produces 8 of the 12 vaccines in its National Immunisation Programme (Marsh, 2020). Cuba bet on biotechnology very early, opening the first research - manufacturing facility in the country in $1981 .{ }^{68}$ Since its establishment in the mid-1980's, the Cuban biotech sector has developed a meningitis $B$ vaccine, and today exports the world's most effective hepatitis $B$ vaccine to more than 30 countries. Recently, it developed the first synthetic vaccine for the prevention of pneumonia and meningitis, which is much cheaper than what is offered by Western pharmaceutical companies (Fawthrop, 2004). More recently, Cuba has developed a vaccine for lung cancer (CIMAvax-EGF), and produced a number of innovative drugs and vaccines as a result of advances in its biotech sector, including haemophilus influenzae type $b$ (Hib) vaccines (O'Farrill, 2018).

Nowadays, most of the biotech industry is concentrated in BioCubaFarma, a state holding created in 2012 with the Government's economic reforms. This organisation of Biotechnology and Pharmaceutical Industries manages the country's efforts toward manufacturing medicines, diagnostics and medical equipment and providing high quality life science services to improve people's health. Another centre of excellence is the Pedro Kouri Institute of Tropical Medicine (IPK) which works closely with the WHO in Geneva (Fawthrop, 2004).

However, some of the attractiveness of investing in Cuba include the country's high potential in tourism, qualified and inexpensive labour, and its geographical location. However, the Cuban economy is vulnerable to external factors, such as climate, and commodity prices. Poor infrastructure, bureaucracy, Cuba's Soviet-style economy, the country's dual currency system, and tighter US restrictions, still hamper foreign investors. ${ }^{69}$ Also, cash-strapped Cuba may also struggle to buy raw materials for large-scale vaccine production (Marsh, 2020).

\section{Capital support and framework}

Former leader Fidel Castro championed a 100\% home-grown biotech sector in the 1980s. Cuba has invested a lot of cash into its state-owned biotech industry, partly so Cuba could become more vaccine self-sufficient in the face of a US trade embargo. As a result of both economic necessity and of Cuba's publicly stated values - has been producing affordable medicines. It is supported by Cuba's medical philosophy, which prioritises prevention - the only viable path for a poor country to provide universal healthcare affordably (O'Farrill, 2018).

BioCubaFarma has consolidated a deep product pipeline that includes prophylactic and therapeutic vaccines. ${ }^{70}$ BioCubaFarma's strength and value derive from a combined network of

\footnotetext{
68 https://www.nature.com/articles/d43747-020-00522-5

${ }^{69}$ Foreign direct investment (FDI) in Cuba: https://www.nordeatrade.com/en/explore-newmarket/cuba/investment

${ }^{70}$ BioCubaFarma: bringing Cuban biopharma to the world: https://www.nature.com/articles/d43747-020-00522-5
} 
34 companies and institutions under one umbrella that collaborate on maximising the impact of their R\&D programmes in the biotechnological and pharmaceutical space. Eight institutions constitute the core of this network, ${ }^{71}$ three of which are involved with vaccines:

- the Center of Genetic Engineering and Biotechnology (CIGB): founded in 1986, it is one of 34 companies and institutes that constitute BioCubaFarma. It develops, manufactures and commercialises human and veterinary vaccines. CIGB makes $60 \%$ of medicines used in Cuba, and 8 of 12 vaccines; ${ }^{72}$

- the Center of Molecular Immunology: the CIM specialises in the development and manufacture of products for the diagnosis and treatment of diseases related to the immune system, and of molecular vaccines for cancer immunotherapy, and

- the Finlay Institute: the IFV is Cuba's pre-eminent vaccine research and production centre. The institute co-ordinates research in immunology, molecular biology, and applied microbiology to develop novel vaccines and the fermentation processes needed for their production. Among IFV's top accomplishments is the development of the first vaccine in the world against meningitis $\mathrm{B}$ almost 30 years ago.

Cuban vaccine manufacturing is a $100 \%$ Government investment. The Ministry of Public Health (MINSAP) is responsible for ensuring the stability of drug prices for the population and has approved prices since 1988, using a methodology endorsed by the Ministry of Finance and Prices, in which the Government of Cuban subsidizes part of the price, as necessary (WHO, 2015a: 43). The Government of Cuban, through MINSAP, has ensured the financial sustainability of the Cuban regulatory agency (CECMED) as an essential component of the national health system with a view to developing local production of drugs and other health technologies that meet international standards (WHO, 2015a: 49). Income generated by vaccine sales abroad will pay for health care, education, and pensions in Cuba, which is what happens with exports of medical services and medicines.

Cuba's Ministry of Foreign Trade and Foreign Investment (MINCEX) ${ }^{73}$ is responsible for directing, carrying out and monitoring implementation of the Cuban Government policy on trade, investment and collaboration abroad. Its main objectives are to diversify its business partners and work towards reorganising trade policy in pursuit of favourable markets for its exports and the diversity and competitiveness of its export items. Cuba has trade relations with over 170 countries (WHO, 2015a: 32).

\section{Pharma growth and vaccine access}

Biotechnology is one of Cuba's largest sources of foreign exchange. However, no reports were found on the contribution of the pharmaceutical sector to gross domestic product (GDP) (WHO, 2015a: 35). Havana's Finlay Institute (formally the National Center for Development of the Meningococcal Vaccine) is a leader in Cuban health technology, producing various vaccines such as the tetanus vaccine vax-TET and a combination vaccine against tetanus and

\footnotetext{
${ }^{71}$ https://www.nature.com/articles/d43747-020-00522-5

72 A socialist approach: https://www.thenews.com.pk/print/787090-a-socialist-approach

${ }^{73}$ Approved by Decree Law 264/2009, the purpose and essential mission of MINCEX are to prepare and propose to the Cuban Government a comprehensive policy on foreign trade activity, the creation of joint ventures, and economic co-operation with other countries, foreign organisations and associations.
} 
diphtheria. It entered into a deal allowing major drug MNC GSK to license its discovery in order to facilitate the first entry of a Cuban medical product into the more lucrative Western market (Fawthrop, 2004).

The biotechnology and pharmaceutical industries have been funded by the State through different plans that have changed over the years. In the case of biotechnology, in its infancy funding was provided directly by the State. In 2001 changes were introduced, and a selffinancing plan was adopted, specifically for current expenditures; investments were the exception and had to be approved centrally. In late 2008, another form of financing was introduced, which had to be approved by the Ministry of Economy and Planning (WHO, 2015a: 28).

Today, Cuba's pharmaceutical industry is increasing in strength. Cuba's entirely stateowned biopharmaceutical industry has been remarkably successful (O'Farrill, 2018). It is distinctive because it is owned by the state and not supported by speculative financing. ${ }^{74}$ BioCubaFarma has an extensive global presence through mixed capital companies in China, Spain, Thailand, and Singapore, solely Cuban-owned companies in Venezuela, Ecuador, Brazil, and Mexico, a representative office in China, and a branch office in Colombia. ${ }^{75}$ The country is developing four COVID-19 vaccines in parallel to help with access: The Finlay Institute of Vaccines is leading on Soberano 02, and also Soberano $01 ;{ }^{76}$ two more, Abdala and Mambisa, are being developed by the Centro de Ingeniería Genética y Biotecnología. Both the institutes are funded and operated by the Cuban Government.

The US embargo, unlikely to be lifted soon, will continue to put legal obstacles for American and other foreign companies. The Government favours investments that provide advanced technology and contribute to the infrastructure. In 2015, Cuba passed a new law Foreign investment Act, which introduced tax incentives for foreign investors, and created a special economic zone (SEZ) with tax and customs breaks, with the hope of attracting more foreign capital to boost its state-dominated economy. However, the latter cannot directly recruit employees. The new legislation opens most of the economy to FDI, except in health, education, media and the military (UNCTAD, 2020: 218). However, the lack of statistical transparency prevents the gathering of reliable data on the amount of FDI inflows. ${ }^{77}$

The greatest challenge to the pharma industry is the yearly review of drug price controls. Every year, drug price increases are limited by CMED (Câmara de Regulação do Mercado de Medicamentos), an arm of Brazil's health regulatory body known as ANVISA (Parrish, 2020).

\section{Vaccine exports and imports}

Many countries, including Spain, Canada, Mexico, Italy and Venezuela continue to trade and invest in Cuba. Therefore, vaccine manufacture has become a major part of the economy.

\footnotetext{
${ }^{74}$ Bhtech (2021). Cuba is developing four vaccines. It wants to vaccinate its entire population by end-2021. 15 February 2021: https://news.besthinditech.com/cuba-is-developing-four-vaccines-it-wants-to-vaccinate-its-entirepopulation-by-end-2021/

75 https://www.nature.com/articles/d43747-020-00522-5

76 Guenot M (2021). Cuba is working on a homegrown COVID-19 vaccine program. It has a history of fighting disease without help from the West. 15 February 2021: https://sports.yahoo.com/cuba-working-homegrowncovid-19-123607295.html

77 Foreign direct investment (FDI) in Cuba: https://www.nordeatrade.com/en/explore-newmarket/cuba/investment
} 
Cuba has exported hundreds of millions of vaccines to more than 40 countries (Marsh, 2020). The Government of Cuba established R\&D institutes that are designed to also facilitate manufacturing of respective products (research-production centres or full cycle institutions), not only to meet local health needs but targeting export markets as well (WHO, 2015a: 3).

Because of the absence of the private pharmaceutical sector in Cuba, all health needs are met through public or state-controlled institutions. Most of the drugs that are produced domestically are not imported in the country, and the price stability is ensured through subsidies by the state and are established through the Ministry of Finance and Prices (WHO, 2015a: 4).

\title{
Positive spillover effects
}

Through the holistic approach with a long-term perspective to promoting and supporting local capacity for pharmaceutical manufacturing, Cuba has developed a good public health strategy with indicators comparable to those of industrialised countries despite limited resources. To date, local production has contributed $65 \%$ to the local health needs, drug prices are generally low compared to the income level of the Cuban population, and the human development index is now comparable to that of the developed countries (WHO, 2015a: 4).

\section{Skills development}

\begin{abstract}
Since 1959, Cuba has invested significant financial resources in the training of human resources and science and technology development. This has influenced the achievements of the Cuban pharmaceutical industry and the population's access to health technologies. In the 1990s, Cuba accounted for $11 \%$ of doctorate-level Latin American scientists. Cuban scientists work in the 50 biomedical research and production facilities which together make up Cuba's state-owned BioCubaFarma Corporation. At the end of 2013, CIGB had more than 21,600 employees, 6,158 of whom were university graduates Of these, 270 had PhDs and 1079 had master's degrees (WHO, 2015a: 18). Hundreds of them highly-skilled professionals deeply integrated within several research-production activities (O'Farrill, 2018). With a research workforce of more than 1,500 , the centre is one of the pre-eminent biotechnology organisations in the Latin American region. ${ }^{78}$ Finlay Institute, one of 20 research centres and 32 companies, employs some 20,000 people that make up the state-run BioCubaFarma corporation (Marsh, 2020). IPK also brings together highly qualified professionals from Harvard Medical School who make up a multidisciplinary team for the comprehensive care of patients (Fawthrop, 2004).
\end{abstract}

In 1986, US-based biotechnology company Chiron developed the technology to obtain a genetically engineered (or DNA recombinant) hepatitis B vaccine; that same year, the Cuban recombinant vaccine was developed using a cheaper method. While not popularly understood outside the country, Cuba's biopharma achievements have been recognised by the international scientific community. In 2005, the Laboratory of Synthetic Antigens, a small lab that belongs to the faculty of chemistry of the University of Havana, won the World Intellectual Property Organization (WIPO) Gold Medal Award for developing the world's first synthetic vaccine (Quimi-Hib) against haemophilus influenza type b (or Hib) (O'Farrill, 2018).

78 https://www.nature.com/articles/d43747-020-00522-5 
Nowadays, Cuba has become a global leader in the South-South transfer of technology, helping low-income countries develop their own domestic biotech capabilities, providing technical training, and facilitating access to low-cost lifesaving drugs to combat diseases such as meningitis B and hepatitis B (WHO, 2015a: 3 ). The success of Cuban R\&D as well as local manufacturing capacity can also be measured in the light of numerous technology transfer deals it has secured with other countries including Algeria, India, Brazil, China, South Africa, Mexico, Argentina, Vietnam, and Malaysia (WHO, 2015a: 4).

State-run media have run lengthy profiles of researchers working at Finlay Institute (Marsh, 2020). Scientists are hailed as heroes in Cuba, a prestige that helps limit brain drain despite low salaries and difficult conditions, as Cuban researchers contend with US sanctions that hamper international collaboration and the purchase of supplies (Marsh, 2020).

However, O'Farrill (2018) found that the Government needs to better understand behaviour in innovative organisations, and which measures will encourage or discourage employee motivation. Important wage increases for highly-skilled professionals have taken place since 2014 especially in the health sector, benefiting more than 440,000 healthcare workers, who in most cases saw their salaries grow by more than $100 \%$ (O'Farrill, 2018). However, these wage increases appear to be negatively impacting the motivational balance of the biotech workforce. The industry has seen $40 \%$ of its workforce quit over the last two years.

\section{Mexico}

Over the course of the twentieth century, state builders created several institutions devoted to the production of vaccines - including the Institute of Hygiene, the Laboratory of the Pharmaceutical Industry, the National Institute of Virology and the Central Laboratory of Reagents - all attached to the MoH (Carrillo, 2017: 140).

The creation of GAP has allowed WHO to directly support vaccine manufacturers in 14 countries, including Birmex, to acquire the capacity to produce inactivated or live attenuated influenza virus (LAIV) vaccine for the population (WHO, 2015b: 1). Vaccination against influenza is a political priority, and there is political will for vaccine production in the country as a means to guarantee the needed supply at a low price. For the purchase of influenza vaccines in particular, the $\mathrm{MoH}$ has a multiannual vaccine purchase agreement with Birmex (for 15 years, starting in 2008). The agreement states that the $\mathrm{MoH}$ must purchase the vaccine through Birmex, with the maximum price set to be equal to the one offered by PAHO's Revolving Fund.

However, Mexico has had repeated stopping and starting of vaccine production under conditions of revolutionary instability (Carrillo, 2017: 138). Nowadays, domestic vaccine development has practically disappeared. It was not intellectual or technical incapacity that influenced the disappearance of national vaccine production but rather economic, political and cultural factors, including strong governments, revolution and civil war, controversies among physicians, rebellions against vaccines, accidents, and the creation, reorganisation and dissolution of institutions (Carrillo, 2017: 140).

- approval by Mexico's pharmaceutical trade association COFEPRIS is a challenge for companies looking to gain market access in Mexico. The approval process for COFEPRIS is relatively quick, usually taking around six months. However, applications 
for inclusion on Mexico's formularies are often subject to delays of up to two years after registration has been completed;

- getting included on the country's three major formularies is an even more important part of achieving market penetration in Mexico. However, the difficulties in this area need to be taken into account (Steele, 2013). Once a drug has been included on the national formulary, it must then seek inclusion on the Mexican Institute of Social Security (Spanish: Instituto Mexicano del Seguro Social, IMSS) formulary and the formulary of the Institute for Social Security and Services for State Workers (ISSSTE);

- Mexico has repeatedly asked for price negotiations in Mexican pesos, however, influenza vaccine prices are currently negotiated in US dollars; a situation that threatens sustained vaccination when there are significant changes in the exchange rate (WHO, 2015b: 4). Once the price is set, the budget is calculated in Mexican pesos (using the official exchange rate for the day) but the payment is not made until the vaccines are delivered (using the day's exchange rate), and

- vaccine price per dose continues to be an important threat for sustained vaccination (WHO, 2015b: 4). Research shows that without justification, influenza vaccines against pandemics have been sold at a much higher price than seasonal vaccines and denounces the transfer of the responsibilities of the company that markets the product to the governments with regard to the compensation for serious illness or death from the vaccine. ${ }^{79}$

\section{Capital support and framework}

Domestic vaccine production has been a political priority, because politicians saw that imports were expensive and also because national security dictated protecting public health (Carrillo, 2017: 135). The state-owned Biological and Reagents Laboratories of Mexico LLC (Birmex), ${ }^{80}$ is the company responsible for the production, commercialisation, distribution, and investigation of biological and reagents in Mexico since in 1999. In 2007, in the context of the Global Pandemic Influenza Action Plan (GAP) of WHO to increase vaccine supply worldwide, Birmex was selected by WHO to be part of the manufacturers grantees. Since then, Birmex has received five grants $(2007,2009,2011,2014$ and 2015$)$, representing $8 \%$ of the total investment. ${ }^{81}$

Vaccine manufacture relies on funding by public-(foreign)private partnerships. Public production assured that currency remained in Mexico, while private manufacturing increased capital flight. Public production concentrated on products that resolved local problems, which was of little or no concern to private production. In public production, all products were generated within the country, while private production required importing finished products or products shipped in bulk. In the public sector, the technical and administrative personnel were Mexican, in the private sector they were foreigners (with the exception of Myn y Zapata Laboratories) (Carrillo, 2017: 136). Access to viral immunity has been in the hands of very few business

\footnotetext{
${ }^{79}$ FORCADES, 2010, p. 246 in Tamez et al., $2016: 16$.

$80 \mathrm{http}: / /$ www.birmex.gob.mx

81 INFLUENZA VACCINE PROJECT AT BIRMEX:

https://www.who.int/phi/8thPartnersMtg2015_Birmex_poster.pdf
} 
firms, including national and international entities and institutions. ${ }^{82} \mathrm{MNCs}$ are responsible for the design, development, production and marketing of vaccines in a market that handles about USD10 billion in annual sales. On the other hand, there are multilateral institutional actors (international organisations and national detection centres) that have the power to concentrate the updated samples and recommend to WHO the strains that will serve as the basis for the annual production of vaccines (Tamez et al., 2016: 17).

\section{Pharma growth and vaccine access}

Mexico's pharmaceutical industry generates revenues of approximately USD11 billion, making it the 11th largest pharma market in the world. In Latin America, Mexico comes in second after Brazil, which leads the region with USD16 billion. ${ }^{83}$

Vietnam's pharmaceutical sector has been overwhelmed by foreign companies in patent and specialty drug segments (EVBN, 2014). However, FDI inflows to Mexico decreased by $5 \%$ to USD33 billion. As usual, the manufacturing sector absorbed almost half of FDI inflows (47\%), with USD16 billion driven by the automotive industry (representing $21 \%$ of FDI) (CITAD, 2020).

Mexico had achieved self-sufficiency in vaccine production, control, storage and distribution, except in the case of the poliomyelitis vaccine, whose production did not always fulfil national demand, and by the end of the 1980s was exporting biological products (including vaccines, mainly for rabies) to fifteen countries in the Caribbean as well as Central and Latin America (Carrillo, 2017: 135). However, from the standpoint of self-sufficiency, not enough vaccines have been produced since 1998 (Tamez et al., 2016).

\section{Vaccine export and imports}

Birmex is responsible for the export of vaccines. A Brazilian Sanofi plant provides bulk influenza vaccines to Birmex. ${ }^{84}$ Each year, Birmex imports, controls and distributes nearly 20 million doses of seasonal influenza vaccine, which are delivered to the institutions of the Health Sector (Mexican Social Insurance Institute, Institute of Social Security and Services of State Workers, Popular Insurance, States' Departments of Health, Pemex health services and the Armed Forces, etc.); these are applied during national vaccination campaigns (Tamez et al., 2016: 13). It plans to import about 870,000 doses of AstraZeneca's COVID-19 vaccine from India in February, as well as producing it locally. ${ }^{85}$ The Government also states that it is not opposed to private companies buying COVID-19 vaccines to distribute to patients who want to pay for the shots. ${ }^{86}$

\footnotetext{
82 Macías-Richard C (2010). Respuestas institucionales y corporativas a la pandemia de 2009: América Latina ante los actores multinacionales en la producción de medicamentos. Desacatos, Guadalajara, 32, 63-88.

83 The Pharmaceutical Industry in Mexico - New Challenges, New Leaders: https://www.russellreynolds.com/sites/default/files/mexican_pharm_trendsreport.pdf

84 Raw I (2019). Developing Countries Can Innovate and Produce Vaccines: The Case of Butantan in Brazil: https://www.intechopen.com/books/vaccines-the-history-and-future/developing-countries-can-innovate-andproduce-vaccines-the-case-of-butantan-in-brazil

${ }^{85}$ Mexico to import 8.70 lakh doses of AstraZeneca vaccine from India. 30 January 2021: https://www.indiatoday.in/coronavirus-outbreak/story/mexico-to-import-astrazeneca-vaccine-from-india-17641752021-01-30

${ }^{86}$ Mexico might allow private firms to buy, distribute vaccines. 29 December 2021:

https://abcnews.go.com/International/wireStory/mexico-private-firms-buy-distribute-vaccines-74937990
} 


\section{Positive spillover effects}

There is evidence exploring the possible spillover effects of the Programa Nacional de Educacion, Salud y Alimentacion (PROGRESA) programme on the wider community, which offered conditional cash transfers (CCTs) in Mexico (Handa et al., 2001; Avitabile, 2012). Significant spillover effects appear to exist among children ages 11-12 years, especially continuation rates for girls (almost 10 percentage points higher). There is also existence of a significant spillover effect of PROGRESA on the health care behaviour of non-beneficiary households. However, results indicate that this spillover effect takes time to manifest itself (Handa et al., 2001: 20). Health interventions can generate spillover effects on the demand for healthcare among individuals who do not belong to the original target group (Avitabile, 2012: 28). Increased demand for Papanicolaou cervical cancer screening among women in rural Mexico was also found (Avitabile, 2012).

\section{Skills development}

The main component of the agreement was an intensive technology transference package for filling/packing the vaccine in a multipurpose plant build by Birmex in the State of Mexico (Tamez et al., 2016). In addition, the influenza project was supported by the Mexican $\mathbf{M o H}$, complemented by Birmex's own budget and grants from the WHO developing country influenza technology transfer project (Ponce-de-Leon et al., 2011). However, Mexico is dependent on foreign institutes and manufacturing laboratories for training and models of manufacture (Carrillo, 2017: 138). In 2008, Birmex established a joint venture with Sanofi-Pasteur for the production of influenza vaccine in Mexico. 


\section{References}

Avitabile, C. (2012). Spillover Effects in Healthcare Programs: Evidence on Social Norms and Information Sharing. Washington, DC: Inter-American Development Bank.

https://www.econstor.eu/bitstream/10419/89024/1/IDB-WP-380.pdf

Baptista, P.N., Magalhães, V., Rodrigues, L.C., Rocha, M.W., \& Pimentel, A.M. (2006). Pertussis vaccine effectiveness in reducing clinical disease, transmissibility and proportion of cases with a positive culture after household exposure in Brazil. Pediatr Infect Dis J, 25, 844-846. DOI: 10.1097/01.inf.0000232642.25495.95

Bates, C. (2011). Emerging market: Brazil. 17 March 2011.

http://www.pmlive.com/pharma_news/emerging_market_brazil_265286

Benjamin-Chung, J., Abedin, J., Berger, D., et al. (2017). Spillover effects on health outcomes in low- and middle-income countries: a systematic review. International Journal of Epidemiology, 46(4), 1251-1276. https://doi.org/10.1093/ije/dyx039

Bhadoria, V., Gobinath, A., Mitra, P., \& Narayan, M. (2012). Transforming India's vaccine market Saving lives, creating value. McKinsey \& Company.

https://www.mckinsey.com/ /media/mckinsey/featured\%20insights/India/Transforming\%20Indias \%20vaccine\%20market/Transforming\%20Indias\%20vaccine\%20market\%20Saving\%20lives\%20 creating\%20valueSept2012.ashx

Brückler, C. (2013). ASEAN: Domestic vaccines manufacturers. 3 December 2013.

http://www.pmlive.com/pharma_intelligence/asean_domestic_vaccines_manufacturers_522262

Carrillo, A.M. (2017). Vaccine production, national security anxieties and the unstable state in nineteenth- and twentieth-century Mexico in 'The politics of vaccination.' Chapter DOI:

https://doi.org/10.7765/9781526110916.00013

Chhabara, R. (2010). Breaking into the Brazilian pharma market. 25 February 2010.

https://www.reutersevents.com/pharma/evidence/breaking-brazilian-pharma-market

Coe, M. \& Gergen, J. (2017). Thailand Country Brief. Sustainable Immunization Financing in Asia Pacific. Washington, DC: ThinkWell. https://thinkwell.global/wp-

content/uploads/2018/09/Thailand-Country-Brief-081618.pdf

Dupas, P., \& Miguel, E. (2016). Impacts and Determinants of Health Levels in Low-Income Countries. Final Draft, April 2016 (Prepared for the Handbook of Field Experiments).

https://web.stanford.edu/ pdupas/Health_DupasMiguel_Handbook.pdf

Edejer, T.T.-T., Aikins, M., Black, R., Wolfson, L., Hutubessy, R., \& Evans, D.B. (2005). Cost effectiveness analysis of strategies for child health in developing countries. BMJ, 331:1177. DOI: https://doi.org/10.1136/bmj.38652.550278.7C

EVBN (2014). Healthcare: research report. EU-Vietnam Business Network, Ho Chi Minh city. https://www.flandersinvestmentandtrade.com/export/sites/trade/files/news/223150528071429/22 3150528071429_1.pdf

Fawthrop T (2004). Cuba Ailing? Not Its Biomedical Industry. 26 January 2004:

https://yaleglobal.yale.edu/content/cuba-ailing-not-its-biomedical-industry 
Fonjungo, F., Banerjee, D., Abdulah, R., et al. (2020). Sustainable Financing for New Vaccines in Indonesia: Challenges and Strategies. Sustainability, 12, 9265.

https://doi.org/10.3390/su12219265

Gadelha, C.A.G., Braga, P.S.D.C., Montenegro, K.B.M., \& Cesário, B.B. (2020). Access to vaccines in Brazil and the global dynamics of the Health Economic-Industrial Complex. Cad. Saúde Pública, 36(supl 2). https://doi.org/10.1590/0102-311x00154519

Ginting, E. (2019). Foreign direct investment is not coming to Indonesia. Really? Opinion piece. 18 September 2019. Asian Development Bank. https://www.adb.org/news/op-ed/foreign-directinvestment-not-coming-indonesia-really-edimon-ginting

Handa, S., Huerta, M.-C., Perez, R., \& Straffon, B. (2001). Poverty, Inequality, and Spillover in Mexico's Education, Health, and Nutrition Program. Washington, DC: International Food Policy Research Institute. https://ageconsearch.umn.edu/record/16437

Homma, A. (2009). The Brazilian vaccine manufacturers' perspective and its current status. Biologicals, 37(3), 173-176. https://doi.org/10.1016/j.biologicals.2009.02.011

IFPMA (2015). TECHNOLOGY TRANSFER: A COLLABORATIVE APPROACH TO IMPROVE GLOBAL HEALTH. 25 January 2015. International Federation of Pharmaceutical Manufacturers \& Associations. https://www.ifpma.org/wpcontent/uploads/2016/01/IFPMA_Technology_Transfer_2015_Web.pdf

IMF (2002). Foreign Direct Investment: Performance and Attraction: The Case of Thailand. https://www.imf.org/external/pubs/ft/seminar/2002/fdi/eng/pdf/brimble.pdf

Jit, M., Dang, T.T., Friberg, I., et al. (2015). Thirty years of vaccination in Vietnam: Impact and cost-effectiveness of the national Expanded Programme on Immunization. Vaccine, 33(Suppl 1), A233-A239. https://doi.org/10.1016/j.vaccine.2014.12.017

Kusuma, D., Thabrany, H., Hidayat, B., McConnell, M., Berman, P., \& Cohen, J. (2017). New Evidence on the Impact of Large-scale Conditional Cash Transfers on Child Vaccination Rates: The Case of a Clustered-Randomized Trial in Indonesia. World Development, 98, 497-505. https://doi.org/10.1016/j.worlddev.2017.05.007

Lahariya, C. (2014). A brief history of vaccines \& vaccination in India. Indian J Med Res, 139(4), 491-511. https://www.ncbi.nlm.nih.gov/pmc/articles/PMC4078488/

Locus Bulletin (2019). Vietnam tops the chart of the world's fastest-growing economies. 9 December 2019. https://locus.sh/resources/bulletin/vietnams-economicgrowth/\#: :text=A\%20recent\%20GDP\%20growth\%20statistics,\%25\%20and\%206\%25\%20CAG $\mathrm{R} \% 20$ respectively

Makenga, G., Stefano, B., Emanuele, M., Trent, C., \& Joachim, A. (2019). Vaccine Production in Africa: A Feasible Business Model for Capacity Building and Sustainable New Vaccine Introduction. Frontiers in Public Health, 7, 56.

https://www.frontiersin.org/article/10.3389/fpubh.2019.00056 
Marsh, S. (2020). Cuba leads race for Latin American coronavirus vaccine. 12 November 2020. https://www.reuters.com/article/us-health-coronavirus-vaccine-cuba-focus/cuba-leads-race-forlatin-american-coronavirus-vaccine-idUSKBN27S1OX

Milken Institute (2016). New Models for Financing Vaccination Programs in Southeast Asia. December 2016. https://milkeninstitute.org/sites/default/files/reportspdf/VaxPrgrmsSEAsia4WEB.pdf

Milstien, J.B., \& Kaddar, M. (2010). The role of emerging manufacturers in access to innovative vaccines of public health importance. Vaccine, 28(9), 2115-2121.

https://doi.org/10.1016/j.vaccine.2009.12.036

Milstien, J.B., Gaulé, P., \& Kaddar, M. (2007). Access to vaccine technologies in developing countries: Brazil and India. Vaccine, 25, 7610-7619.

https://doi.org/10.1016/j.vaccine.2007.09.007

Nair, A. (2020). Covid-19 Exposes Indian Pharma's Overdependence On China. 22 September 2020. https://www.relocatemagazine.com/articles/enterprise-coronavirus-exposes-indianpharmas-overdependence-on-china-au20

Nhan Dan (2020). Opening the door for made-in-Vietnam vaccine production. 6 February 2016: https://en.nhandan.org.vn/society/item/4016202-opening-the-door-for-made-in-vietnam-vaccineproduction.html

O'Farrill, A.C. (2018). How Cuba Became a Biopharma Juggernaut. 5 March 2018.

https://www.ineteconomics.org/perspectives/blog/how-cuba-became-a-biopharma-juggernaut

Ozawa, S., Mirelman, A., Stack, M.L., Walker, D.G., Levine, O.S. (2012). Cost-effectiveness and economic benefits of vaccines in low- and middle-income countries: A systematic review. Vaccine, 31, 96-108. https://doi.org/10.1016/j.vaccine.2012.10.103

Padmanabhan, S., Amin, T., Sampat, B. et al. (2010). Intellectual property, technology transfer and manufacture of low-cost HPV vaccines in India. Nat Biotechnol, 28, 671-678. https://doi.org/10.1038/nbt0710-671

PATH (2018). Enhancing influenza vaccine development in low-resource countries: : pandemic preparedness through seasonal sustainability. September 2018.

https://path.azureedge.net/media/documents/PATH_BARDA_influenza_report_FINAL.pdf

Pagliusi, S., Rustan, R., Huang, W., \& Nguyen, T. (2014). Better vaccines for healthier life. Part I. Conference report of the DCVMN International 14th Annual General Meeting Hanoi, Vietnam.

Vaccine, 32(48), 6325-6329. https://doi.org/10.1016/j.vaccine.2014.05.075

Pitisuttithum, P., \& Wirachwong, P. (2019) A review of epidemic preparedness for influenza through local vaccine production: national security for Thailand. Human Vaccines \& Immunotherapeutics, 15(10), 2440-2445. DOI: 10.1080/21645515.2019.1638205

Plotkin, S., Robinson, J. M., Cunningham, G., lqbal, R., \& Larsen, S. (2017). The complexity and cost of vaccine manufacturing - An overview. Vaccine, 35(33), 4064-4071.

https://doi.org/10.1016/j.vaccine.2017.06.003 
Ponce-de-Leon, S., Velazquez-Fernandez, R., Bugarin-González, J., et al. (2011). Domestic influenza vaccine production in Mexico: A state-owned and a multinational company working together for public health. Vaccine, 29(1), A26-A28. https://doi.org/10.1016/j.vaccine.2011.04.121

Possas, C., de Souza Antunes, A., Mendes, F., et al. (2015). Access to new technologies in multipatented vaccines: challenges for Brazil. Nat Biotechnol, 33, 599-603.

https://doi.org/10.1038/nbt.3244

Rauch, S., Jasny, E., Schmidt, K.E., \& Petsch, B. (2018). New Vaccine Technologies to Combat Outbreak Situations. Front Immunol, 19. https://doi.org/10.3389/fimmu.2018.01963

Raw, I., \& Higashi, H.G. (2008). Self-sufficiency and innovation in vaccine production and public health. Estudos avançados, 22(64), 155-170. https://core.ac.uk/download/pdf/268333494.pdf

Regan, K. (2018). From Vietnam to the world: How PATH helped ready locally-made influenza vaccine for global use. 24 September 2018. PATH. https://www.path.org/articles/global-healthsecurity-syringe/

Saha, M. (2021). SII \& Bharat Biotech could see profits on low costs as India rolls out Covid vaccination. 16 January 2021. https://theprint.in/economy/sii-bharat-biotech-could-see-profits-onlow-costs-as-india-rolls-out-covid-vaccination/586243/

Steele, B. (2013). The Route to Market Access in Mexico. 24 July 2013.

https://www.reutersevents.com/pharma/evidence/route-market-access-mexico

Sur, D., Ochiai, R.L., Bhattacharya, S.K., et al. (2009). A Cluster-Randomized Effectiveness Trial of Vi Typhoid Vaccine in India. N Engl J Med, 361, 335-344. DOI: 10.1056/NEJMoa0807521

Tamez, S., Eibenschutz C., Zafra, X., \& Raquel Ramírez, R. (2016). Public-private articulation in the production of vaccines in Mexico. Saúde debate, 40(111). http://dx.doi.org/10.1590/01031104201611101

ThinkWell (2017). Vietnam Country Brief. August 2017. https://thinkwell.global/wpcontent/uploads/2018/09/Vietnam-Country-Brief-081618.pdf

UNCTAD (2020). WORLD INVESTMENT REPORT 2020. United Nations Conference on Trade and Development. https://unctad.org/system/files/official-document/wir2020_en.pdf

Xue, Q.C., \& Ouellette, L.L. (2020). Innovation policy and the market for vaccines. Journal of Law and the Biosciences, 7(1), 1-41. https://doi.org/10.1093/jlb/lsaa026

WHO (2011). Local Production for Access to Medical Products: Developing a Framework to Improve Public Health. World Health Organization.

https://www.who.int/phi/publications/Local_Production_Policy_Framework.pdf

WHO (2015a). Cuban experience with local production of medicines, technology transfer and improving access to health. World Health Organization.

https://www.who.int/phi/publications/Cuba_case_study121115.pdf

WHO (2015b). Technical Report of Consultations with the Mexican Secretary of Health on Key elements of sustainability for local production of influenza vaccine within the context of global 
pandemic preparedness. Consultation held in Mexico, December 2014 - April 2015. World Health Organization.

https://www.who.int/influenza_vaccines_plan/resources/Mexico_Assessment_Report.pdf?ua=1

WHO (2017). Made in Viet Nam Vaccines: efforts to develop sustainable in-country manufacturing for seasonal and pandemic influenza vaccines. Consultation held in Viet Nam April - June 2016. World Health Organization. Licence: CC BY-NC-SA 3.0 IGO. https://apps.who.int/iris/bitstream/handle/10665/254184/WHO-HIS-TTi-17.2eng.pdf? sequence $=1$ \&isAllowed $=y$

\section{Suggested citation}

Tull, K. (2021). Economic impact of local vaccine manufacturing. K4D Helpdesk Report 974. Brighton, UK: Institute of Development Studies. DOI: 10.19088/K4D.2021.034

\section{About this report}

This report is based on six days of desk-based research. The K4D research helpdesk provides rapid syntheses of a selection of recent relevant literature and international expert thinking in response to specific questions relating to international development. For any enquiries, contact helpdesk@k4d.info.

K4D services are provided by a consortium of leading organisations working in international development, led by the Institute of Development Studies (IDS), with Education Development Trust, Itad, University of Leeds Nuffield Centre for International Health and Development, Liverpool School of Tropical Medicine (LSTM), University of Birmingham International Development Department (IDD) and the University of Manchester Humanitarian and Conflict Response Institute (HCRI).

This report was prepared for the UK Government's Foreign, Commonwealth and Development Office (FCDO) and its partners in support of pro-poor programmes. Except where otherwise stated, it is licensed for non-commercial purposes under the terms of the Open Government Licence v3.0. K4D cannot be held responsible for errors, omissions or any consequences arising from the use of information contained in this report. Any views and opinions expressed do not necessarily reflect those of FCDO, K4D or any other contributing organisation.

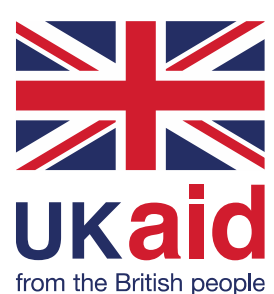

(C) Crown copyright 2021. 